\title{
Unorden
}

\section{Å skape et inkluderende arbeidsmarked}

Om inkludering av unge, funksjonsnedsatte og seniorer i Norden (et sammendrag)

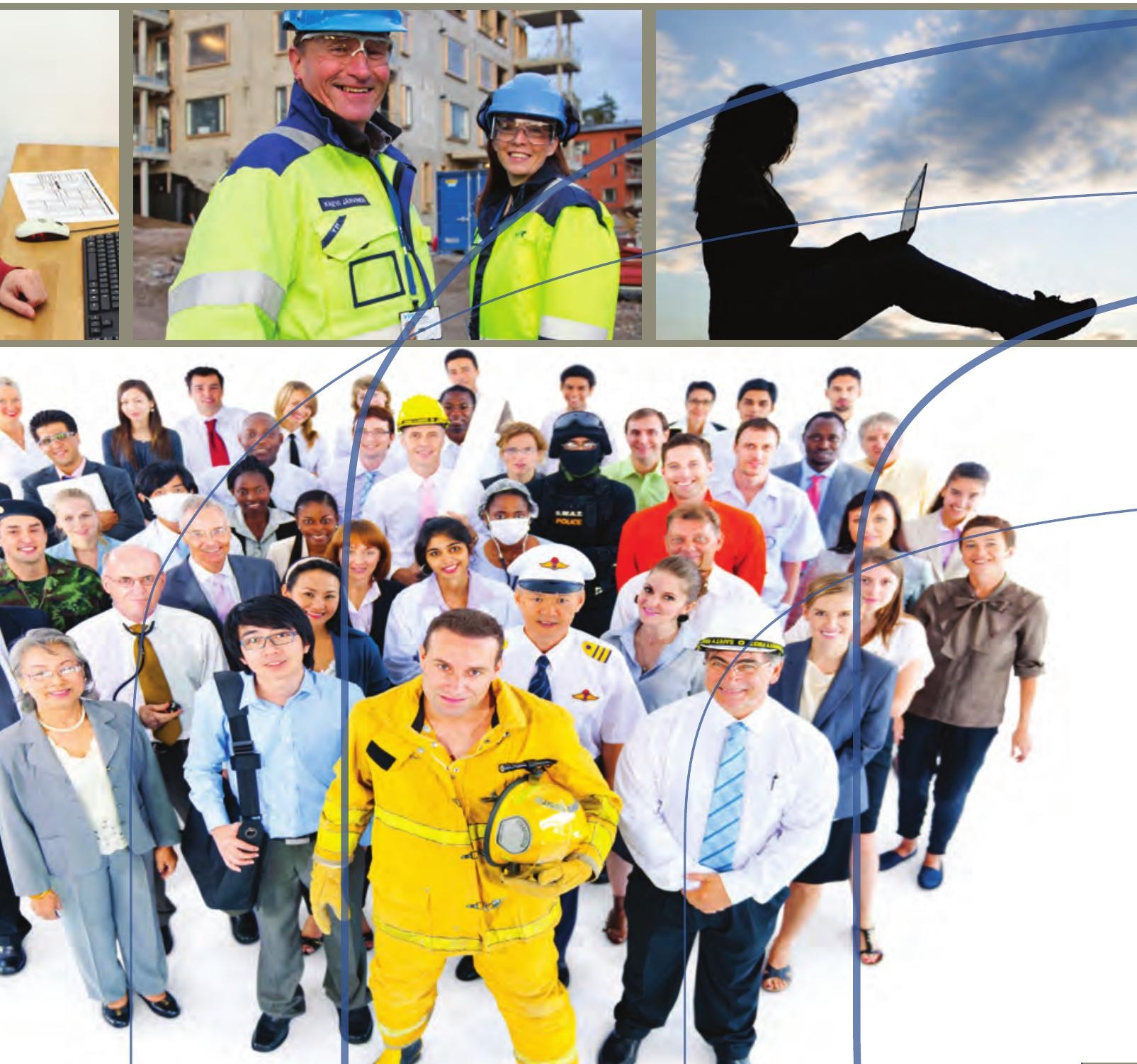



I nordon 



\section{Å skape et inkluderende arbeidsmarked}

Om inkludering av unge, funksjonsnedsatte og seniorer i Norden (et sammendrag)

Bjørn Halvorsen, Ole-Johnny Hansen, Jenny Tägtström og Ragna Flø

TemaNord 2013:537 


\section{Å skape et inkluderende arbeidsmarked}

Om inkludering av unge, funksjonsnedsatte og seniorer i Norden (et sammendrag)

Bjørn Halvorsen, Ole-Johnny Hansen, Jenny Tägtström og Ragna Flø

ISBN 978-92-893-2552-3

http://dx.doi.org/10.6027/TN2013-537

TemaNord 2013:537

(C) Nordisk ministerråd 2013

Layout: Hanne Lebech

Omslagsfoto: ImageSelect; Olli Häkämies

Trykk: Rosendahls-Schultz Grafisk

Opplag: 416

Printed in Denmark

Denne rapporten er gitt ut med finansiell støtte fra Nordisk ministerråd. Innholdet i rapporten avspeiler imidlertid ikke nødvendigvis Nordisk ministerråds synspunkter, holdninger eller anbefalinger.

\section{www.norden.org/no/publikasjoner}

\section{Det nordiske samarbeidet}

Det nordiske samarbeidet er en av verdens mest omfattende regionale samarbeidsformer. Samarbeidet omfatter Danmark, Finland, Island, Norge og Sverige samt Færøyene, Grønland og Åland.

Det nordiske samarbeidet er både politisk, økonomisk og kulturelt forankret, og er en viktig medspiller i det europeiske og internasjonale samarbeid. Det nordiske fellesskapet arbeider for et sterkt Norden i et sterkt Europa.

Det nordiske samarbeidet ønsker å styrke nordiske og regionale interesser og verdier i en global omverden. Felles verdier landene imellom bidrar til å styrke Nordens posisjon som en av verdens mest innovative og konkurransekraftige regioner.

\section{Nordisk ministerråd}

Ved Stranden 18

DK-1061 København K

Telefon (+45) 33960200

www.norden.org 


\section{Innhold}

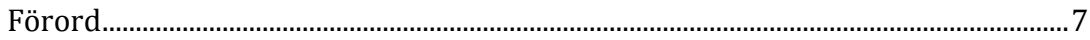

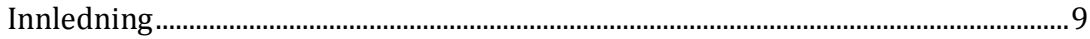

1. Unge på kanten - om inkludering av utsatte ungdommer ....................................13

1.1 Samordnet innsats...................................................................................... 14

$1.2 \quad$ Politikk og praksis .................................................................................... 17

$1.3 \quad$ Eksempler på god praksis i de nordiske landene......................................19

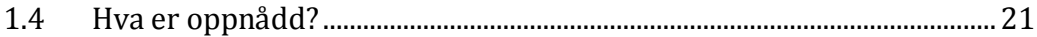

1.5 Hva kan vi lære av naboen?.............................................................................22

$1.6 \quad$ Figur- og tabellvedlegg - Ungdom................................................................ 26

2. Et arbeidsmarked for alle? En dokumentanalyse av de nordiske landenes jobbstrategier for personer med funksjonsnedsettelse ..............................................2 29

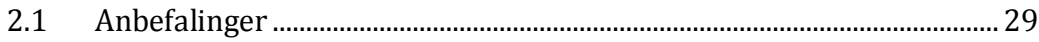

2.2 Jobbstrategiene $i$ hvert enkelt land ............................................................. 34

2.3 Analyse av landenes sysselsettingsstrategier ……………………………..... 37

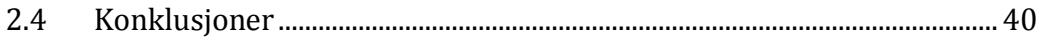

2.5 Figur- og tabellvedlegg - Et arbeidsmarked for alle? ............................... 44

3. Det dreier seg om helse og arbeidsglede. Om seniorer, arbeid og pensjonering i Norden...................................................................................................... 47

3.1 Konklusjoner ................................................................................................. 47

3.2 Anbefalinger ................................................................................................. 52

3.3 Hva gjøres? Om politikk, programmer og innsatser .................................5 55

3.4 Hva kan vi lære av naboen?.......................................................................59

3.5 Definisjoner og forklaringer ........................................................................ 62

$3.6 \quad$ Figur- og tabellvedlegg - Seniorer.................................................................. 63

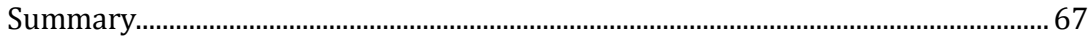





\section{Förord}

Högt deltagande i arbetslivet är fundamentet för den nordiska välfärden och vår höga materiella standard. I alla de nordiska länderna är målet att så många som möjligt ska kunna delta i arbetslivet. Arbete ger identitet och bidrar till ekonomisk självständighet, deltagande och social tillhörighet. Det ger individen en möjlighet till att utveckla och använda sina förmågar.

Mycket står rätt till med den nordiska välfärden men det finns varningssignaler. Ett stort antal unga faller ut från skola och utbildningssystem och många får därmed problem med att komma in på arbetsmarknaden. Personer med funktionsnedsättning har problem med att få arbete och seniorer avgår i förtid från arbetslivet.

Arbetsinkluderingsprojektet studerar vad som görs och vad som är uppnått i de nordiska länderna för att inkludera dessa grupper på arbetsmarknaden. Projektet pekar bland annat på att åtgärder som sätts in bör vara tudelade: individuellt anpassade lösningar och universella lösningar oavsett det gäller unga, personer med funktionsnedsättning eller seniorer.

Gemensamt för projektets rekommendationer (tilrådinger) är att utveckla och styrka det nordiska arbetet för ökad inkludering på arbetsmarknaden. Åtgärder som införs och metoder som utvecklas i ett av de nordiska länderna, kan vara av intresse och ha överföringsvärde för grannen.

Nordens Välfärdscenter, Stockholm februari 2013

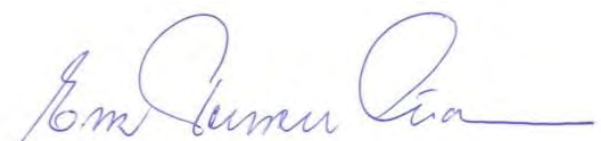

Ewa Persson Göransson

Direktör för Nordens Välfärdscenter 


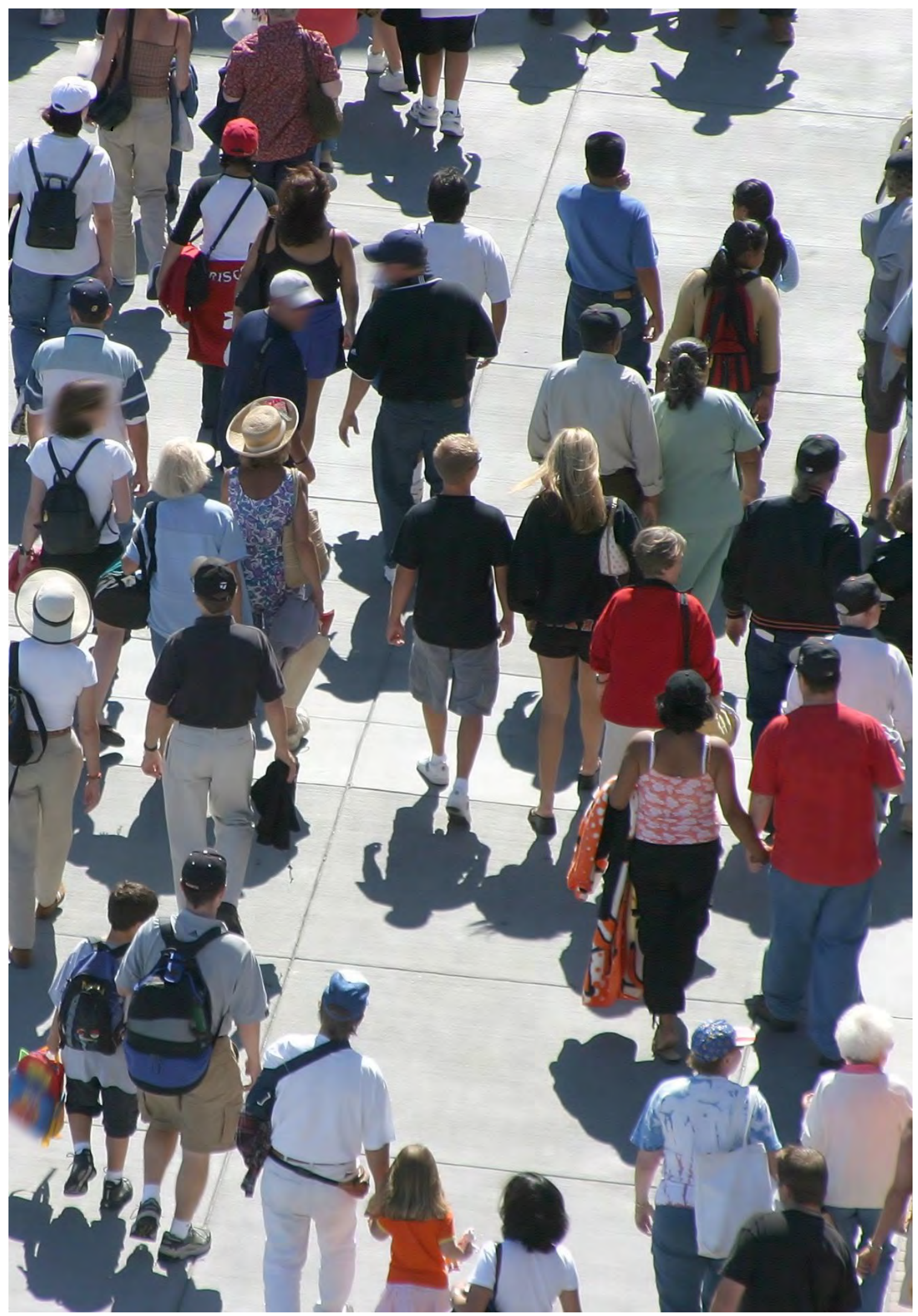




\section{Innledning}

Prosjektet Inkludering av utsatte grupper i arbeidsmarkedet i de nordiske landene har kartlagt og analysert hva de nordiske landene gjør og oppnår i arbeidet med å inkludere utsatte grupper i arbeidsmarkedet. Prosjektet har hatt tre delprosjekter:

- Ungdom, med rapporten "Unge på kanten - om inkludering av utsatte ungdommer."1

- Funksjonshemmede, med rapporten "Et arbeidsmarked for alle? En dokumentanalyse av de nordiske landenes jobbstrategier for personer med funksjonsnedsettelse." ${ }^{2}$

- Seniorer, med rapporten "Det dreier seg om helse og arbeidsglede. Om seniorer, arbeid og pensjonering i Norden." ${ }^{3}$

Arbeidsinkluderingsprosjektet inngår i Nordisk ministerråds "Globaliseringsinitiativ om sunnhet og helse." Prosjektet har vært forankret i nordisk embetsmannskomité for sosialpolitikk (EK-S), og med embetsmannskomiteene for arbeidsmarkedspolitikk (EK-A) og utdanningspolitikk (EK-U) som viktigste interessenter. Til prosjektet har det vært knyttet en referansegruppe med deltakere fra hvert av de fem nordiske landene pluss en person fra EK-A og en kontaktperson fra Nordisk ministerråds sekretariat.

Arbeidskraften er vår viktigste ressurs, og i alle de nordiske landene er målet at flest mulig skal kunne delta i arbeidslivet. Arbeid gir identitet og bidrar til økonomisk selvstendighet, deltakelse og sosial tilhørighet. Det gir den enkelte anledning til å utvikle og bruke sine evner. Det er betydeli-

\footnotetext{
1 Nordisk ministerråd, TemaNord 2012: 004 og 005.

2 Nordisk ministerråd, TemaNord 2012: 551.

${ }^{3}$ Nordisk ministerråd, TemaNord 2013: 519.
} 
ge forskjeller i levekår mellom dem som har arbeid og dem som har liten eller ingen tilknytning til arbeidslivet.

Globalisering og omstillinger i arbeidslivet i de nordiske landene gir store gevinster i form av større produksjon, høyere produktivitet og høyere materiell velstand. Samtidig ser vi at blant annet ungdom, personer med funksjonsnedsettelser og seniorer kan ha problemer med å komme inn i arbeidslivet eller å beholde arbeid. Det samme gjelder personer med innvandrerbakgrunn. Arbeidsinkluderingsprosjektet studerer hva som gjøres og oppnås i de nordiske landene med å inkludere ungdom, funksjonshemmede og seniorer i arbeidslivet, blant annet med bakgrunn i den globale, økonomiske krisen som satte inn høsten 2008.

Dette heftet gir en kort sammenfatning av de tre rapportene i prosjektet. 



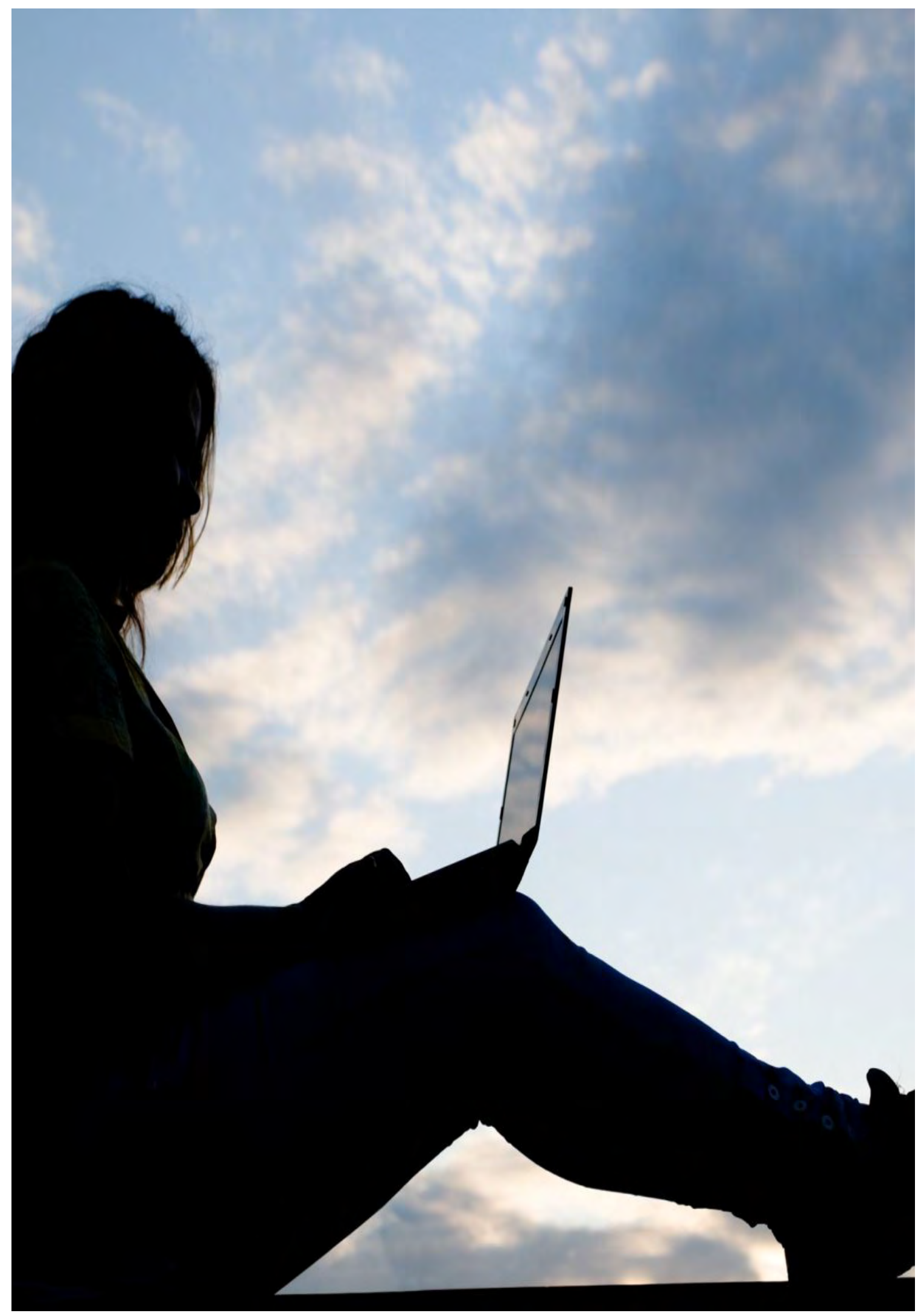




\section{Unge på kanten - om inkludering av utsatte ungdommer}

Ungdomsarbeidsløsheten er høy og vedvarende i mange av de nordiske landene, spesielt i Sverige og Finland der det er mellom 20-25 \% ungdomsledighet. I de andre landene er ledigheten lavere, men også der er ledigheten betydelig høyere enn i befolkningen som helhet.

Prosjektet dokumenterer at mellom seks-åtte av ti ungdommer fullfører videregående skole i løpet av fem år. Det er altså ganske mange unge som ikke fullfører. Noen tar det igjen senere gjennom voksenopplæring. Mange som ikke fullfører videregående utdanning står svakt rustet på arbeidsmarkedet.

Prosjektet slår fast at mellom fem til $10 \%$ av ungdomskullene har stor risiko for å falle ut av skole og arbeidsliv og at om lag 2-3\% allerede er utenfor. Det er fare for at betydelige deler av ungdomskullene blir stående utenfor arbeidsliv og deltakelse i samfunnet ved inngangen til voksenlivet og kanskje i store deler av sitt voksne liv. Det gjelder spesielt om utenforskapet blir varig og får bite seg fast. Se figur- og tabellvedlegget.

Blant unge som faller utenfor, er det mange med innvandrerbakgrunn, helsemessige og/eller sosiale problemer eller familie- og miljøproblemer og i noen tilfeller rusproblemer og/eller kriminalitet. Tendensen er den samme i alle de nordiske landene.

Prosjektet ser på hva som gjøres for å motvirke ungdomsarbeidsløshet og hva som fremmer inkludering av unge i utdanning og arbeid. Målgruppen er ungdom i alderen 15-24 år. 


\section{Konklusjoner og anbefalinger}

- Motvirke "en tapt generasjon" i arbeidsliv og samfunn

- La ikke unge i utkanten av skole eller arbeidsliv få bli utenfor

- Sørg for bedre gjennomføring og mindre frafall i videregående skole/gymnas

- Systematisk forsøksvirksomhet for å utvikle og forbedre tjenester og arbeidsmåter

- Mer oppmerksomhet og innsats rettet mot arbeidsliv og virksomheter

- Bedre kunnskap om resultater og effekter av programmer og innsatser

- Utvikle det nordiske samarbeidet om arbeidsinkluderingspolitikken

Arbeidsmarkedstiltakene ble trappet sterkt opp i alle de nordiske landene i 2009 og 2010 og er blitt videreført i 2011. Et bredt sett av innsatser og tiltak er satt inn. Dette kjennetegner den aktive arbeidsmarkedspolitikken i de nordiske landene. Tiltak mot ungdomsledighet må dreie seg om mer enn generelle og kortsiktige konjunkturtiltak. Det må legges vekt på større innsats mot strukturell ledighet og inkludering av vanskeligstilte på arbeidsmarkedet. I Danmark og Island finner vi en målrettet innsatsprofil. Norge har en mer universell profil, og Finland og Sverige ligger midt imellom. Det er viktig å ha både generelle og mer målrettede innsatser.

\subsection{Samordnet innsats}

Ungdom som sliter må fanges opp tidlig og få hjelp raskt. Mange har sammensatte problemer og behov og trenger koordinert innsats fra skole, sosial- og helsetjenester og arbeidsformidling. Man bør lytte til den unge selv og trekke dem og deres familie og miljø aktivt med i prosessen. Det er viktig å støtte de vanskelige overgangene fra grunnskole til videregående skole, fra videregående skole til arbeid/lærepraksis/arbeidspraksis eller studier og fra studier til arbeidsliv. Ikke minst må man finne en god "match" mellom hva den unge ønsker og arbeidslivets behov, forventninger og krav.

Mange av de gode innsatsene og resultatene går på tvers av tradisjonelle politikk-, administrasjons- og fagområder. Samordnet innsats gjennom henholdsvis arbeidsmarkedstiltak, utdanning og sosial- og helsetje- 
nester er viktig. På samme måte må det vektlegges et godt samarbeid og god forankring i arbeidslivet. Mye av det nordiske samarbeidet er imidlertid organisert og forankret i tradisjonelle områder: arbeidsmarkedspolitikk, utdanningspolitikk, helsepolitikk og sosialpolitikk.

\section{Yrkes- og fagutdanningene bør styrkes og forankres bedre i arbeidslivet}

Mangel på læreplasser er et problem. Små og store virksomheter bør få støtte og hjelp til å ta inn lærlinger, og i den forbindelse samarbeide med den videregående skolen (gymnasiet).

Helhet, samordning, eget medansvar og egen medvirkning samt individuell og varig veiledning og oppfølging ser ut til å være stikkordene for vellykkede "reiser mot voksenlivet" for unge med sammensatte behov og problemer.

\section{Systematisk forsøksvirksomhet og erfaringsbank}

I alle de nordiske landene foregår det forsøksvirksomhet med nye tiltak og metodikk for å inkludere ungdom i skole og arbeid. Prosjektene drives av dyktige og engasjerte fagfolk. Ofte ender fors $ø$ kene ikke i permanente løsninger og tjenestetilbud. De inngår sjelden i en samlet strategi for å utvikle politikk, tjenester, virkemidler, arbeidsmåter og kompetanse. Vi ser at det er behov for en mer samlet og systematisk tilnærming og strategi for å utvikle, gjennomføre og formidle forsøksvirksomhet. Det gjelder både på nasjonalt og på nordisk plan. Bedre dokumentasjon i form av forskningsbasert evaluering og dokumentasjon av resultater og effekter er nødvendig. Det vil gi bedre overførings- og læringsverdi til andre.

NVC anbefaler at det etableres en nordisk, webbasert "idé- og erfaringsbank" for "god praksis"-eksempler og evaluerte forsøksprosjekter for inkludering av ungdom i utdanning og arbeid i de nordiske landene. 


\section{Mer fokus mot arbeidsliv og virksomheter}

Mye av innsatsen og virkemidlene i arbeidsmarkedspolitikken er rettet mot enkeltpersoner, det vil si elever, studenter og arbeidssøkere - altså mot tilbudssiden i arbeidsmarkedet. Mindre innsats og virkemidler er orientert mot etterspørselssiden i arbeidsmarkedet, det vil si mot virksomheter, arbeidsgivere og personalforvaltere. Det er viktig å "matche" tilbud og etterspørsel - på individplan så vel som på samfunnsplan.

Arbeidsgivere må gjøres trygge på å unngå tap ved å ta imot ungdom som sliter. I dag hersker det usikkerhet, uvitenhet og frykt for merarbeid. Prøveansettelser, trainee-ordninger og midlertidig tilsetting osv. kan være tiltak for å åpne inngangen til arbeidslivet.

Lønnssubsidiering, skattelette eller direkte økonomisk støtte til bedrifter ved utprøving eller ansettelse av lærlinger og personer med nedsatt arbeidsevne kan være én vei å gå.

NVC anbefaler de nordiske landene å:

- Sette konkrete mål for gjennomføringsgrad i skolen, for overgang til arbeid, deltakelse i arbeidslivet og arbeidsledighet blant unge i for eksempel alderen 16-19 år og 20-24 år.

- Utvikle bedre og mer sammenlignbar statistikk om gjennomføringen av programmer, virkemidler og innsatser for å inkludere utsatte grupper i arbeidslivet.

- Utvikle og bruke gode resultatindikatorer som ledd i gjennomføring, utfall, oppfølging og utvikling av inkluderingspolitikken.

- Vurdere å fremme mer komparativ (nordisk) evalueringsforskning på dette området.

Dette kan være et grunnlag for bedre tjenester og mer effektiv ressursbruk for å få flere unge inkludert i skole og arbeid og for å motvirke varig utenforskap blant unge. 


\section{Utvikle det nordiske samarbeidet om arbeidsinkluderingspolitikken}

Et bedre kunnskapsgrunnlag er viktig for å kunne gjennomføre politikken på en god måte, lære av erfaringene og resultatene for derved å utvikle politikken videre. Det er nyttig å ha et komparativt nordisk perspektiv. Det er også hensiktsmessig å tilpasse dette til det utrednings- og utviklingsarbeidet som skjer på området gjennom OECD og EU. Det kan være et nordisk mål å bidra til å videreutvikle disse politikkområdene mer i retning av samordnet og helhetlig arbeids-, utdannings- og sosialpolitikk i de nordiske landene.

\subsection{Politikk og praksis}

Rapporten gjennomgår aktuelle politiske innsatser i perioden 2005-2010 for å holde yrkesdeltakelsen oppe og motvirke økt arbeidsledighet. Materialet bygger på en systematisk kartlegging i hvert av de nordiske landene. Alle landene har både generelle virkemidler (åtgärder) rettet mot hele befolkningen (inklusive unge) og også mer målrettede innsatser spesielt rettet mot ungdom. Tyngdefordelingen og innholdet er litt forskjellig landene imellom.

Den generelle økonomiske politikken og den generelle, aktive arbeidsmarkedspolitikken har stor betydning i tillegg til innsatsene overfor arbeidsledige ungdommer generelt og for mer vanskeligstilte ungdommer spesielt. Det er ikke lett å si hva som er et godt blandingsforhold, men det synes viktig at det er en bevisst og gjennomtenkt blanding av både mer generelle innsatser og mer målrettede innsatser.

Danmark har over tid gjennomført omfattende strukturreformer som gjelder organiseringen av offentlige arbeidsmarkeds- og velferdstjenester: Samordnete "jobcentre" i kommunene ("one-stop-shops"), fleksibilitet og økte kombinasjonsmuligheter mellom arbeid og stønad ("flexicurity") og forholdsvis liberale regler for ansettelse, oppsigelse og midlertidige jobber ("lett at hyre - lett at fyre"). Innsatsene overfor unge har vært prioritert i en omfattende "Beskæftigelsesstrategi overfor unge." Det legges vekt på tidlig innsats, tett oppfølging og gjensidige krav og forventninger mellom den unge og jobbsenteret. Utdanning og arbeids- 
inkludering gjennom erhvervs-/yrkesfag og "praksispakker" er også prioritert, og disse er blitt styrket under krisen. Den nye regjeringen i Danmark høsten 2011 har styrket ungdomsutdanningene ytterligere som ledd i å bekjempe ungdomsledigheten.

Finland har satset mye på den videregående skolen, først og fremst innen allmenne studieforberedende linjer, men etter hvert også mer gjennom programmene "yrkesstart" og "läroavtalsutbildning" (lærlingeutdanning), blant annet ved en rekke ungdomsverksteder. På flere av disse områdene er det oppnådd gode og lovende resultater. Samfunnsgarantien for unge gir garanti for tiltak ved arbeidsløshet etter tre måneder og ved lønnssubsidiering gjennom "Sanssikortet." Ungdomsledigheten har vært høy i mange år, men ledighetsveksten kan se ut til å ha bremset opp. Finland har imidlertid likevel mange unge "utenfor" (nær 10 \% NEET), og mange unge på sosialhjelp (cirka $11 \%$ ), selv om tallet har gått nedover $\mathrm{i}$ de senere årene.

Island har tradisjonelt hatt høy yrkesdeltakelse og lav arbeidsledighet i befolkningen totalt, så vel som blant unge, men med et stort frafall i den videregående skolen. Tidligere har man likevel kunnet få seg arbeid selv om man ikke hadde fullført utdanning. Island er samtidig det nordiske landet som fikk den største kollapsen i økonomien høsten 2008, og det førte også til en jobbkrise på Island. Det er satt inn kraftige tiltak rettet mot unge, blant annet gjennom programmet "Unge i aktivitet" ("Ungt fólk til athafna"). Tidlig innsats, råd, veiledning og utdanning har stått sentralt. En god del lokale innsatser og prosjekter er blitt satt i verk under krisen. Veksten i ungdomsledigheten kan foreløpig se ut til å ha stanset opp, men den er fortsatt høy (2011).

Norge har i flere år satset på omfattende organisasjons- og strukturreformer og - innsatser: Samarbeidsavtaler om et mer inkluderende arbeidsliv (IA-avtale), "NAV-reform" og "innholdsreformer i NAV" har alle hatt som mål å inkludere flere i arbeid. Systematisk individuell vurdering ("arbeidsevnevurdering") og oppfølging er en sentral, ny metodikk ved NAV-kontorene. Det gjelder spesielt personer med nedsatt arbeidsevne. Norge har også en tiltaksgaranti og en oppfølgingsgaranti for unge ledige i aldersgruppen 20-24 år, en garanti om arbeidsmarkedstiltak for unge under 20 år som er uten skoleplass eller arbeid og en nasjonal strategiplan for arbeid og psykisk helse. I tillegg er det innført et "Kvalifiserings- 
program" for personer med nedsatt arbeidsevne (ofte unge) som står langt unna en jobb og som trenger omfattende bistand og oppfølging for å oppnå det. "Ny GIV" er et nytt og bredt anlagt program for samarbeidssatsing for å forebygge og motvirke frafall i skolen (2011). I Norge virker det likevel som det er den generelle økonomiske politikken og den generelle, aktive arbeidsmarkedspolitikken som kan ha hatt størst betydning.

I Sverige er "Jobbgarantin för ungdomar" den viktigste satsingen mot ungdomsledigheten. Det er en omfattende satsing på individuell kartlegging, veiledning, arbeidspraksis, opplæring og utdanning. Resultatene er ganske gode. Ungdom omfattes også av mer generelle arbeidsmarkedssatsinger ("Nystartsjobb," "Instegsjobb") og andre generelle programmer, der lønnssubsidiering ofte er et viktig element. Det er blant annet gjennomført reduserte arbeidsgiveravgifter for å stimulere sysselsettingen blant unge. Dessuten er restaurantmomsen senket for blant annet å stimulere til flere jobber for unge i den bransjen. Fra høsten 2011 gjennomføres det reformer i grunnskole og gymnasiet, blant annet for å øke gjennomføringen i skolen og forbedre den yrkesrettede utdanningen. I tillegg er det mer målrettede programmer orientert mot avgrensede grupper med særskilte utfordringer og behov. Ungdomsledigheten er imidlertid fortsatt høy, med fare for å bite seg fast.

\subsection{Eksempler på god praksis i de nordiske landene}

Rapporten diskuterer erfaringer ved utvalgte forsøksprosjekter og eksempler på god praksis i de nordiske landene. Hva gjør de som lykkes med å inkludere unge som står utenfor skole og arbeidsliv? Eller kanskje helst med å forebygge og motvirke at slikt skjer? Rapporten bygger på en utvalgt eksempelsamling som er nærmere omtalt i Nordens Välfärdscenters hefte "Inspiration för inkludering" (2011). ${ }^{4}$ For eksempel:

${ }^{4}$ Se www.nordicwelfare.org/arbetsinkludering/ 
- Ungdomsverksteder/produksjonsskoler og lignende med yrkesopplæring og -praksis.

- Hjelp og avklaring til utdannings- og yrkesvalg, og personlig "coaching" eller mentorskap med voksne yrkesforbilder.

- Tverrsektorielle og tverrfaglige samarbeidsløsninger mellom f. eks. skole, arbeidsliv, arbeidsmarkedstjenester og eventuelt helse- og sosialtjenester.

- Individuelle "matchingsaktiviteter" mellom den unges ønsker og planer og mulighetene i det lokale arbeidsliv. Reell involvering av de unge selv.

Rammebetingelser og anbefalinger som erfaringsmessig er viktig for god gjennomføring av praksisforsøk:

- Grundig kartlegging av den unges historikk og kompetanse

- Den unges egen medvirkning, spesielt i egen handlingsplan. Lytte til og ta den unge på alvor.

- Sterk individuell støtte og oppfølging av voksne med kompetanse som tydelig viser at de bryr seg, som setter grenser, er støttende og oppmuntrer til mestring.

- Voksne som har kompetanse på veiledning.

- Fleksibilitet med hensyn til løsninger som er tilpasset den enkeltes behov, aller helst gjennom skole og arbeidspraksis i samarbeid og kombinasjon.

- Hyppig kommunikasjon omkring konkrete løsningsstrategier.

- Voksne i systemet med god oversikt over virksomheter og mulige arbeidsplasser. Samarbeid mellom skole, arbeidsliv, familie og kommune.

- Hyppig kommunikasjon med foreldre og støtte til foreldre.

- Systematisk evaluering av gjennomføring og resultater, fortrinnsvis med sammenligningsalternativer eller kontrollgrupper.

Det kan være nyttig å samle, systematisere, sammenstille og informere om gode praksiseksempler og prosjekter, slik at andre kan bli inspirert og lære av det. Det gjelder både nasjonalt og på nordisk plan. NVC anbefaler at det etableres en felles, nordisk webbasert "erfaringsbank" for slike 
prosjekter. Vi viser til NVCs websider, og heftet "Inspiration för inkludering" (NVC 2011).

NVC tilrår at det utvikles mer systematisk arbeid med gode praksiseksempler og forsøksvirksomhet med virkemidler (åtgärder), programmer og arbeidsmåter som grunnlag for å utvikle tjenestetilbud, arbeidsmåter og erfaringsbasert kompetanse i de nordiske landene. Det er da en stor fordel om flere slike forsøk kan gjennomføres på en slik måte at de kan vise til dokumenterte resultater og effekter. Dette er viktig for at de skal kunne ha best mulig overføringsverdi til andre. Slike evalueringer bør også kunne inngå i en nordisk "erfaringsbank" som nevnt over. Dette vil også passe godt inn i EUs "open method of coordination" med vekt på systematisk praksiserfaring gjennom "peer reviews."

\subsection{Hva er oppnådd?}

Alle de nordiske landene har både styrket og innført spesielle tiltak overfor arbeidsløsheten generelt og har prioritert innsats overfor ungdom. Det er både likheter og forskjeller når det gjelder gjelder omfang og hvilke typer innsatser som er satt inn. Dette gjennomgås nærmere i rapporten "Unge på kanten."

Aktiviseringsinnsatsen overfor unge er blitt styrket med et bredt spekter av programmer og virkemidler i Danmark. Også på Island er arbeidsmarkedsinnsatsen blitt trappet meget kraftig opp under krisen, både rettet mot alle arbeidsløse og ikke minst mot unge. Spekteret av virkemidler og innsatser er smalere enn i Danmark. Arbeidsplassforankrede veilednings- og kvalifiseringsinnsatser og utdanningsinnsatser dominerer både $\mathrm{i}$ Danmark og på Island, blant annet gjennom "produksjonsskoler." I Danmark har ungdomsledigheten fortsatt å øke i 2010 og 2011 - på tross av innsatsene. Det er derfor satt inn nye styrkingstiltak overfor unge i 2011 og i 2012.

I Finland og Sverige er også arbeidsmarkedsinnsatsen overfor unge blitt kraftig trappet opp. Økningen er mindre i Norge; på grunnlag av bedre arbeidsmarkedssituasjon og noe mer vekt på en mer arbeidsorientert økonomisk politikk. I Finland og Sverige er det satset mye på lønnssubsidier som virkemiddel for å øke bedriftenes etterspørsel etter blant 
annet unge arbeidsledige. Dette kan synes effektivt i mer målrettede programmer og som ledd i samlede "pakketilbud" med individuell oppfølging, slik som f. eks. "Sannsi-kortet" i Finland. Det er også satset mye på utdanningstiltak, ikke minst yrkesutdanning.

Flere unge enn tidligere er blitt gående i lengre tid på arbeidsmarkedstiltak i (krise)årene 2008-2010. Dette er spesielt tilfelle på Island og i Sverige. I Danmark gjennomgår mange unge relativt korte aktiviseringsforløp, til en viss grad også i Norge. Jo lengre tid en går på tiltak, desto lavere blir som oftest sannsynligheten for å komme i jobb. For utdanningstiltak kan det imidlertid være omvendt: mer varige tiltak kan ha større og mer langsiktig effekt, spesielt i en lavkonjunktur.

Utfallet eller resultatene av innsatsene studeres fortrinnsvis ved tall for hvor mange som kommer i arbeid etter gjennomførte tiltak/ åtgärder/programmer. Hovedbildet er at cirka 40-50 \% av unge (20-24 år) kommer i arbeid etter gjennomførte arbeidsmarkedstiltak gjennom den offentlige arbeidsformidlingen. Noen går også til (videre) utdanning, mens andre går over på andre stønadsordninger. Overgangsraten til arbeid varierer over tid og mellom ulike typer innsatser og programmer i hvert av landene. Overgangsratene til arbeid er blitt klart lavere under kriseårene 2009-2010 enn i de gunstigere årene forut for dette.

Hvilke typer tiltak eller innsatser gir best resultat? Eller best effekt i forhold til innsatsen? Det kan ikke dette prosjektet trekke slutninger om. Her må man blant annet ta hensyn til egenskaper og forskjeller mellom personer som deltar på ulike typer tiltak eller som ikke gjør det (seleksjon). Rapporten avsluttes derfor med en drøfting av spørsmål om resultatmåling og effekter av ulike typer programmer og innsatser. Konklusjonen er at det må være mye å hente ved å utvikle og bruke mer systematisk kunnskap om dette. NVC anbefaler derfor at det utvikles og tas i bruk mer systematisk evaluering av gjennomførte innsatser og tiltak - både på nasjonalt og nordisk plan. 


\subsection{Hva kan vi lære av naboen?}

Her trekker rapporten fram noen eksempler på strategier, innsatser og programmer i hvert av de nordiske landene, for inspirasjon og læring av hverandre.

Danmark har en helhetlig og intensiv ungdomspolitikk og ungdomssatsing med blant annet tiltak rettet mot unge utenfor skole og arbeid, produksjonsskoler og i erhvervs- grunnutdanning. Innsatsene er blitt trappet kraftig opp gjennom krisen, og inkludering av ungdom har vært høyt prioritert. Det har gitt resultater, men noe færre ungdommer har kommet $\mathrm{i}$ arbeid etter gjennomførte tiltak i 2009-2010 enn tidligere. Ungdomsledigheten har økt igjen i 2010-2011, og innsatsen er derfor blitt ytterligere styrket. Man har ikke noen samlet "ungdomsgaranti" for tilbud om bistand og aktivitet for langtidsledige, men rask intervensjon, tidlig og tett oppfølging, raske tiltak, en gjennomført "rett-og-plikt-ideologi" og fleksible ansettelsesformer ("flexicurity" - "lett at hyre, lett at fyre"). Det er fokus på tidlig og aktiv innsats, og utdanning har første prioritet for unge som er uten utdanning og under offentlig omsorg. Veien til jobb skal fortrinnsvis gå gjennom utdanning, men noen kan ha behov for å komme ut i praksis før de kan se meningen i å ta utdanning. Mye av innsatsen foregår gjennom ordinært arbeidsliv. Det bidrar til forankring og fotfeste. Virkemidler og arbeidsmåter i arbeidsformidling og -inkludering blir utviklet gjennom systematisk forsøksvirksomhet med kontrollgrupper og evaluering i regi av Arbeidsmarkedsstyrelsen.

I Finland er det relativt høy gjennomføringsgrad og gode resultater i skolen, men mange unge utdannes likevel til arbeidsledighet. Arbeidsløsheten blant unge er høy både i yrkesfag og blant unge akademikere. Ganske mye av utdanningsinnsatsen i videregående skole synes å være rettet mot yrkesfag, og yrkesutdanningen kan virke ganske praksisorientert. Arbeidsmarkedsinnsatsen overfor unge består mest av generelle veilednings- og formidlingstjenester og arbeidstrening. For mer vanskeligstilte unge skjer mye av arbeidsmarkedsinnsatsene i skjermede arbeidsmarkedstiltak og rehabiliteringstjenester. Spørsmålet er om det gir god effekt med hensyn til overgang til arbeid 
og fotfeste i arbeidslivet? Erfaringene er gode med oppsøkende arbeid overfor de unge som faller fra. ${ }^{5}$

Island har tradisjonelt hatt meget høy deltakelse i arbeidslivet og lav ledighet, men det ble nødvendig med kraftig og rask omstilling som følge av finanskrisen fra 2008. Det kan se ut til at man har sett mye til Danmark og vært raske til å trappe opp nye tiltak som blant annet produksjonsskoler og lignende. Yrkesrettede kurs og andre utdanningstiltak har økt mye i omfang og betydning. Flere unge går lengre på tiltak enn før. Andelen som hittil har kommet i arbeid etter gjennomførte tiltak er nokså lav - rundt 30 \% kom i jobb i 2009. Hva skjer med dem som ikke kommer i jobb eller arbeidsrelatert utdanning? En utfordring for Island kan være å finne ut av dette og sette inn gode tiltak. Hva gjøres med det høye frafallet i skolen? Island kan ha noe å lære bort om kraftige omstillinger, nytenkning, kreativitet, fleksibilitet, utradisjonelle løsninger og tiltak.

I Norge ser det ut til at det er den generelle økonomiske politikken og den generelle, aktive arbeidsmarkedspolitikken som er de viktigste faktorene bak den relativt lave arbeidsledigheten. Ungdom, langtidsledige og innvandrere er prioriterte grupper innen den generelle satsingen. Individuell vurdering av arbeidsevnen og tett oppfølging for dem som trenger det, er det sentrale i metodikken. "Ungdomsgarantiene" viser imidlertid ikke spesielt gode resultater, isolert sett. Det nye og mer målrettede "Kvalifiseringsprogrammet" rettet mot personer som trenger ekstra bistand og oppfølging for å komme i arbeid, viser imidlertid ganske lovende resultater. Det landsdekkende prosjektet "Ny GIV" som ble satt i gang i 2011 i regi av Kunnskapsdepartementet skal forebygge og redusere frafall i den videregående skolen. Tidlig og forebyggende inkluderingspolitikk i barnehage og grunnskole er også viktig i Norge. Det er også diverse målrettede og avgrensede inkluderingsprosjekter i regi av Barne-, likestillings og inkluderingsdepartementet. En utfordring her kan synes å være mangel på systematisk evaluering og omsetting av vellykkede prosjekter til nasjonal politikk og innsats.

${ }^{5}$ Pekka Myrskyläs undersökelse av "Unga utanför," Arbets- och näringsministeriets publikationer 12/2011 www.tem.fi/julkaisut 
I Sverige kan det virke som om den store ungdomsledigheten ganske lenge var et forholdsvis lite fokusert tema politisk, på tross av høy ungdomsledighet i mange år. Mye av diskusjonen om ungdomsledigheten dreide seg om statistikken og hva denne inneholdt om arbeidsløse studenter i arbeidskraftsundersøkelsene (AKU). Ungdomsinnsatsene er imidlertid blitt trappet kraftig opp under finanskrisen, men flere går lengre på tiltak og færre kommer i arbeid etter giennomførte tiltak (åtgärder). Mye av innsatsene under"Jobbgarantin för ungdomar" gir likevel ganske gode resultater. Det er blitt satset mye på skattefradrag og andre former for lønnssubsidiering. De mer målrettede delene av dette ser ut til å bidra til gode resultater, mens mer generelle skattelettelser kan synes å gi mindre sysselsettingseffekt.

I 2011 ble det satt i gang en ny utdanningspolitisk satsing gjennom "Gymnasiereformen" i Sverige for blant annet å forebygge og redusere frafall i den videregående skolen. Reformen omfatter også yrkesutdanninger. Ungdomsstyrelsen i Sverige tar initiativ til - og systematiserer og formidler erfarings- og evalueringskunnskap fra mange forsøks- og utviklingsprosjekter. Det er også gode evalueringer av innsatsen, ikke minst gjennom IFAU. 6

\section{Kilder og referanser}

For kilder og referanser, se hovedrapporten Unge på kanten. Om inkludering av utsatte ungdommer.

${ }^{6}$ Institutet för arbetsmarknadspolitisk utvärdering (IFAU) www.ifau.se 


\subsection{Figur- og tabellvedlegg - Ungdom}

\section{Høy ungdomsledighet og market økning!}

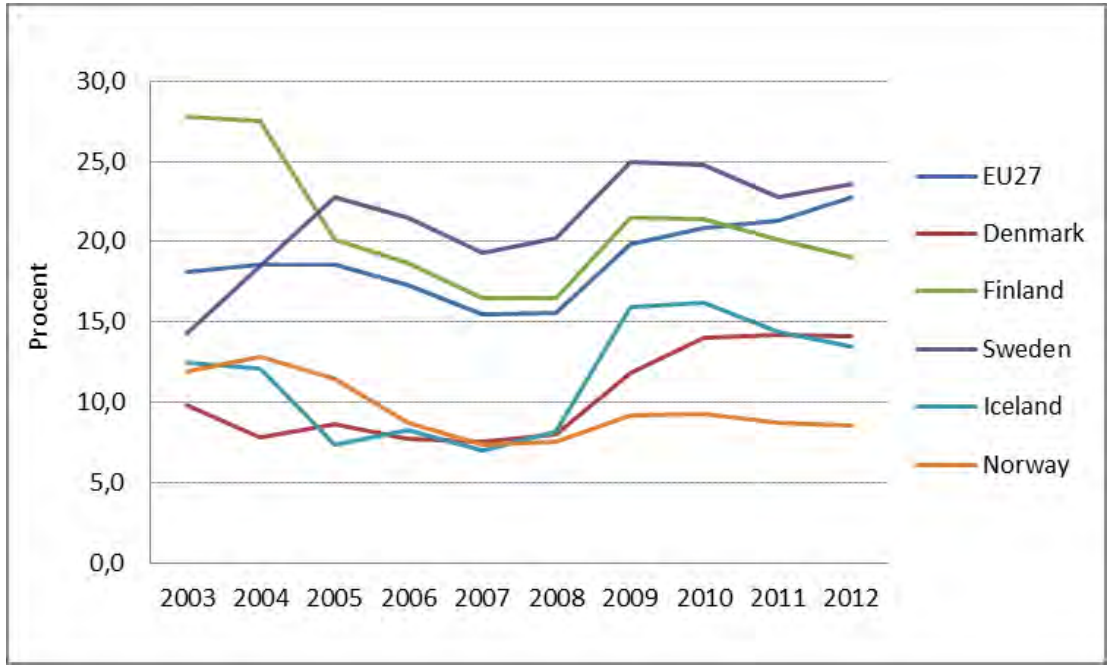

Arbeidsløse unge mellom 15-24 år i de nordiske lande og EU 27 2005-2011. Prosent av arbeidsstyrken i aldersgruppen.

Kilde: Eurostat Labour Force Surveys: Unemployment rates by sex, age and nationality (\%) [Ifsa_urgan] 


\section{De fleste unge i Norden gjennemfører videregående skole, men det er ganske mange som ikke gjør det også!}

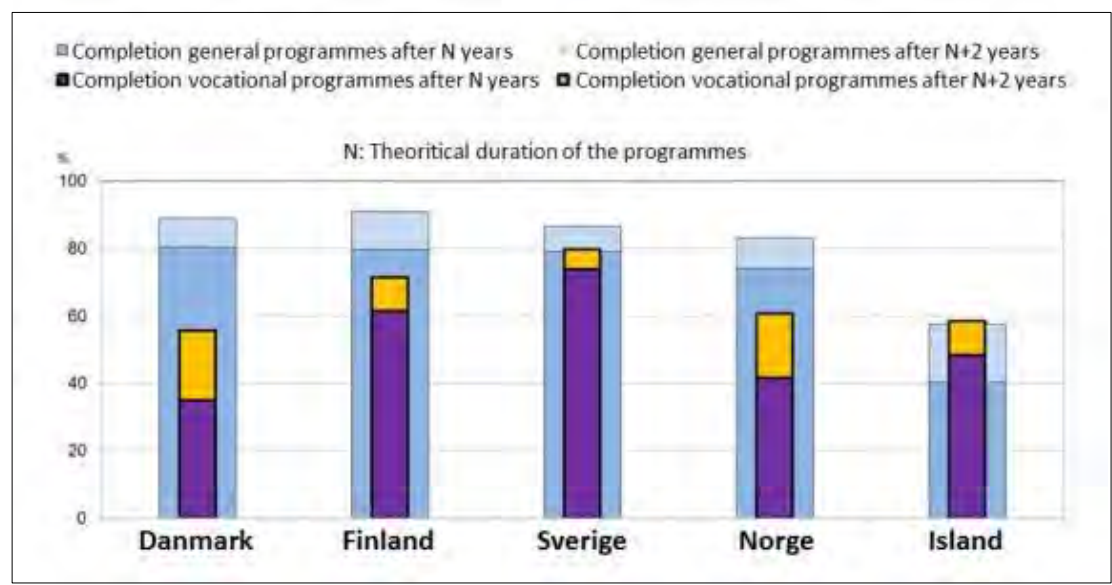

Andel unge i de nordiske landene som gjennemførte vidaregående utdanning i løpet av normert tid. Källa: OECD Education at a Glance 2011. (www.oecd.org/edu/eag2011)

Ungdom på kanten av arbeidsmarkedet i de nordiske land 2008/2009 (\% av kohorter)

\begin{tabular}{|c|c|c|c|c|c|}
\hline & DK & $\mathbf{F I}$ & IC & NO & SE \\
\hline $\begin{array}{l}\text { Langtidsarbeidsledige (> } 1 \text { år), \% av alle arbeidsledige under } \\
\text { (15-24 år) }\end{array}$ & 4,0 & 4,5 & 3,25 & 2,0 & 4,5 \\
\hline $\begin{array}{l}\text { Unge (20-24 år) som verken er i utdanning, arbeid eller } \\
\text { arbeidsrettet optrening (NEET) (2011 tall) }\end{array}$ & 16,0 & 9,25 & 26,0 & 20,0 & 8,0 \\
\hline $\begin{array}{l}\text { Unge (15-24 år) som verken er i utdanning, arbeid eller } \\
\text { arbeidsrettet optrening (NEET) (2011 tall) }\end{array}$ & $\begin{array}{r}5,25 \\
(6)\end{array}$ & $\begin{array}{l}8,5 \\
(9)\end{array}$ & $\begin{array}{r}3,0 \\
(6)\end{array}$ & $\begin{array}{l}5,5 \\
(9)\end{array}$ & $\begin{array}{l}8,5 \\
(8)\end{array}$ \\
\hline $\begin{array}{l}\text { Unge (18-24 år) som mottar ökonomisk Sosialhjelp/- } \\
\text { bistand/forsørgningsstød }\end{array}$ & 10,0 & 11,0 & 6,05 & 5,0 & 9,0 \\
\hline Unge (20-34 år) på förtidspensjon (o.l) & 1,8 & 1,8 & 3,3 & 2,0 & 2,6 \\
\hline
\end{tabular}

Sources: NVC +. OECD (2010) Off to a Good Start? Jobs for Youth. OECD (2010) sickness, disability and work. Breaking the Barriers. 


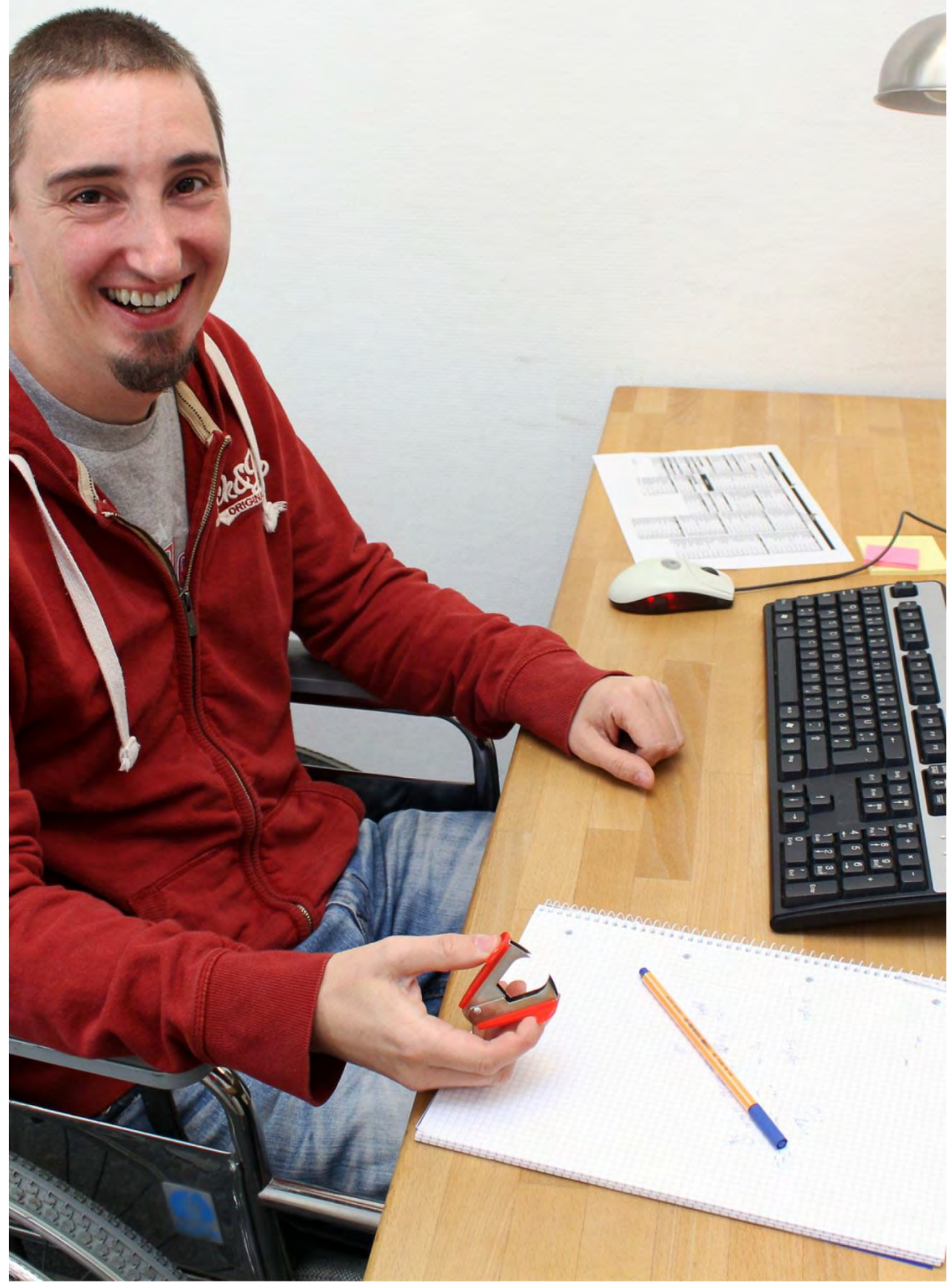




\section{Et arbeidsmarked for alle? En dokumentanalyse av de nordiske landenes jobbstrategier for personer med funksjonsnedsettelse}

Denne rapporten tar utgangspunkt i de nye politiske satsingene (jobbstrategiene) på området sysselsetting av personer med funksjonsnedsettelse i de nordiske landene. Rapporten, som er en dokumentanalyse av jobbstrategiene, beskriver fellestrekk og ulikheter i de politiske satsingene som er på trappene de nærmeste årene.

\subsection{Anbefalinger}

På tross av mangeårige politiske intensjoner om å få flere med nedsatt funksjonsevne i arbeid og et bredt spekter av innsatser for å få dette til, gjenstår det mange utfordringer. Nordens Välfärdscenter (NVC) tar her et bredt perspektiv på anbefalingene for hvordan flere kan komme i arbeid. NVC har opparbeidet kunnskap gjennom ulike prosjekter som vi velger å trekke inn $\mathrm{i}$ anbefalingene i tillegg til annen forskningsbasert litteratur på området.

NVC anbefaler en kombinasjon av at kravene til virksomhetene styrkes, samtidig som de får økt bistand i form av tilretteleggingsstøtte, rådgivning og oppfølging. Vi mener at det er behov for en bredere og sterkere satsing på å utnytte de mulighetene som hjelpemidler og teknologi gir for at flere skal kunne jobbe. Vi må også investere i å få unge med funksjonsnedsettelse raskt inn i arbeidslivet. Inkludering må starte tidlig. 


\section{Styrk kravene til universell utforming i arbeidslivet}

Politiske reguleringer og intervensjoner må til for å bygge ned samfunnsskapte barrierer som hindrer deltakelse i arbeidslivet. Tilgjengelighetstiltak bør ikke bare være et virkemiddel knyttet til enkeltpersoner, men innlemmes som en del av arbeidsmiljølovgivningen for offentlig og privat virksomhet.

For at personer med funksjonsnedsettelse skal kunne delta i arbeidslivet på lik linje med andre, er tilgjengelighet en forutsetning. De største utfordringene er knyttet til å gjøre eksisterende omgivelser universelt utformet enten det gjelder bygninger, transport eller IKT-systemer. Så lenge tilgjengelighetstiltak ses som et virkemiddel knyttet til enkeltpersoner, vil det ta lang tid å redusere fysiske barrierer i arbeidslivet. Krav til universell utforming bør innlemmes på virksomhetsnivå som en del av arbeidsmiljølovningen. Virksomheter bør innarbeide handlingsplaner for tilgjengelighetstiltak og sikre budsjettmessig oppfølging. Planleggingen må bygge på en bred vurdering av interesser, der kostnader og nytte avveies i forhold til økt effektivitet av et bedre utformet arbeidsmiljø. Krav til tilgjengelighet kan også kombineres med økonomiske insentiver for virksomhetene.

\section{Styrk satsingen på hjelpemidler og teknologi}

Utnytt det potensialet som ligger i bruk av hjelpemidler og teknologi. Ny teknologi kan gi nye jobbmuligheter. Rask tilgang til hjelpemidler og teknologi er en forutsetning for å bli vurdert på lik linje med andre. Arbeidsgivere må få lettere tilgang til spesialkunnskap, og rådgivningen må skje virksomhetsnært der behovet oppstår. For unge med funksjonsnedsettelse er det viktig at teknologien tas tidlig i bruk, allerede i skolen.

En rekke undersøkelser understreker betydningen av tilrettelegging i arbeidslivet for personer med funksjonsnedsettelse og viser til et uutnyttet potensial av teknologi for nye arbeidsplasser. Teknologiforandringene skjer stadig raskere, og det åpner seg nye muligheter for å kompensere for funksjonsnedsettelser. Ordinær teknologi kan også inneholde støttefunksjoner som kan gi økt selvstendighet.

Teknologien kan også skape nye barrierer om ikke løsninger og produkter tilpasses funksjonshemmedes behov. Det er behov for økt kunnskap om hvordan vi kan utnytte teknologien og legge til rette for gode løsninger for personer med sansetap og kognitive funksjonsnedsettelser i 
arbeidslivet. Det er også behov for bedre kunnskap om løsninger og opplæring for IT-ansvarlige og arbeidsgivere på arbeidsplassen.

\section{Styrk satsingen for å gi unge med funksjonsnedsettelse rask tilgang til arbeidslivet}

Personer med funksjonsnedsettelse er en heterogen gruppe. Det gjelder ikke minst for unge med funksjonsnedsettelse. Fordi behovene varierer, må også innsatsene variere. Det må bli økt fokus på "matching" av de unges ønsker og kompetanse i forhold til arbeidslivets forventninger og krav. Arbeidssøkere som trenger det, må få støtte i arbeidssøkerprosessen.

\section{Bedre støtte i de vanskelige overgangene}

Overgangen mellom skoler, utdanningsinstitusjoner, praksisplasser (lærlingeplasser) og arbeid er en kritisk fase for alle og spesielt for personer som har behov for bistand eller tilrettelegging. Overganger krever samordnet og helhetlig innsats mellom flere sektorer. Koordineringsansvaret må være plassert.

Helhetlig og tidlig planlegging, "skreddersøm", og fleksible løsninger kan skape muligheter. Ofte kommer planleggingen for sent i gang, og nødvendige hjelpemidler eller annen tilrettelegging er ikke på plass ved oppstart. For mange med funksjonsnedsettelse må flere livsområder ses i sammenheng. Tilgjengelig bolig, transportmuligheter eller praktisk bistand er elementer som må tas med i planleggingen ved valg av skoler, utdanning og arbeid.

\section{Bedre tilgang til veiledning om utdannings- og jobbmuligheter}

For å få en ansettelse kreves relevante kvalifikasjoner. God veiledning om utdannings- og yrkesvalg er sentralt for å øke mulighetene på arbeidsmarkedet. Det må fokuseres på opplæring og utdanninger som gir jobbmuligheter.

Betydningen av utdanning for å få arbeid er viktigere for personer med funksjonsnedsettelse enn for befolkningen for øvrig. Utdanningssystemet 
må sikre at personer med funksjonsnedsettelse får samme mulighet som andre til yrkesfaglig eller teoretisk utdannelse.

\section{Inkludering må starte tidlig}

Manglende tilrettelegging av opplæringstilbud og lav tilgjengelighet i skolebygg og utemiljø er barrierer mot deltakelse i skole og fritid ${ }^{7}$. Barn og unge med funksjonsnedsettelse deltar i mindre grad enn barn flest i organiserte fritids- og idrettsaktiviteter. Manglende samvær med andre i skole og fritid vil blant annet kunne bidra til manglende sosial læring. Dette kan påvirke mestringsopplevelse og identitetsutvikling, ikke bare under skolegang og utdanning, men også i forhold til troen på egne muligheter på arbeidsmarkedet.

\section{Øk kunnskapen om sysselsetting og funksjonsnedsettelse blant innvandrere}

Innvandrere med funksjonsnedsettelse kan risikere å bli en særlig utsatt gruppe på arbeidsmarkedet, der det kan bli snakk om en dobbel stigmatisering. Det er lite forskning som belyser forholdet mellom etnisitet, sysselsetting og funksjonsnedsettelse. Det er derfor behov for større oppmerksomhet og kunnskap om denne gruppen.

Ingen av de nordiske jobbstrategiene for personer med funksjonsnedsettelse omtaler utfordringer rundt en mer heterogen og flerkulturell befolkning i de nordiske landene. Flere innvandrere vil også ha funksjonsnedsettelser og utfordringer på arbeidsmarkedet.

${ }^{7}$ Trender i funktionshinderpolitiken i Norden (Nordiska Handikappolitiska Rådet 2012). 


\section{Styrk innsats og oppmerksomhet mot arbeidsgivere og virksomheter}

Arbeid systematisk med kunnskap, bevisstgjøring og holdningsendringer. Ikke gjør dette bare gjennom holdningskampanjer, men gjennom rådgivning og oppfølging for å redusere arbeidsgivers opplevelse av risiko ved å tilsette arbeidssøkere med funksjonsnedsettelse. Ha større fokus på mangfold, fleksibilitet og kompetanse enn selve funksjonsnedsettelsen.

Mangfold er en styrke for en arbeidsplass. Mange virksomheter vet dette, men mangler konkret kunnskap om hvordan arbeidsplassen kan tilrettelegges for at mangfold kan realiseres. Arbeidsgivere kan oppleve en målkonflikt mellom press på virksomhetens lønnsomhet og effektivitet og den enkeltes tilretteleggingsbehov. Dette må også tas på alvor. Sørg for god balanse mellom krav til arbeidsgivere, økonomiske insitamenter og kompensasjon for merutgifter.

Rådgivning, bedre kobling mellom arbeidssøkere og virksomheter og oppfølging og støtte i forlengelsen av en kontrakt er viktige elementer for å redusere arbeidsgivers opplevelse av risiko. Samtidig må også arbeidsgivere ta et medansvar for å flytte fokus til den enkeltes kompetanse, egenskaper og ressurser fremfor funksjonsnedsettelsen ved rekruttering. Arbeidsgivere må også, sammen med hjelpeapparatet, ta et medansvar for å speile de ressursene som mangfold utgjør i arbeidslivet og på andre arenaer.

\section{Styrk nordisk samarbeid og forskning om hva som skal til for å få flere i arbeid}

I årene som kommer vil det bli gjennomført mange nasjonale evalueringer av jobbstrategiene for personer med funksjonsnedsettelse i de nordiske landene. Det vil kunne øke fokus på og gi bedre evidensbasert kunnskap om arbeidsmarkedspolitiske innsatser overfor personer med funksjonsnedsettelse og bedre kunnskapen om de mest effektive tiltakene.

Manglende inkludering av personer med funksjonsnedsettelse er en felles nordisk utfordring. Utveksling av erfaringer og resultater, et bedre statistikkgrunnlag og mer systematisk kunnskap på nasjonalt og nordisk nivå vil kunne bidra til å utvikle arbeidsmarkedspolitikken for denne målgruppen. Forsøk som gjennomføres og metodikk som utvikles i enkeltland, kan være av interesse og ha overføringsverdi til andre nordiske land. 


\subsection{Jobbstrategiene i hvert enkelt land}

Alle de nordiske landene har nye politiske satsinger i form av overordnede strategier eller jobbstrategier for at flere personer med funksjonsnedsettelse skal kunne delta i arbeidslivet. Rapporten ser nærmere på landenes politiske satsinger for å få flere med funksjonsnedsettelse i arbeid og belyser forskjeller og likheter i valg av tiltak de nærmeste årene. Full deltakelse og likestilling er det overordnede målet i politikken for mennesker med funksjonsnedsettelse. Personer med funksjonsnedsettelse møter barrierer som reduserer mulighetene for deltakelse på en rekke områder, som for eksempel i arbeidslivet, i høyere utdanning, i boligmarkedet og i fritids- og kulturliv.

Strategiene som beskrives her, er fortrinnsvis nye tiltak og satsingsområder i strategiperioden. De gir derfor ikke et fullstendig bilde av det enkelte lands samlede arbeidsmarkedspolitiske satsinger. Strategiene må ses i lys av de innsatser de forskjellige regjeringene har sett behov for å supplere i forhold til allerede eksisterende tiltak.

\section{Danmark}

Den danske regjeringen la i april 2009 frem en ny fireårig strategi: ${ }^{8}$ Handicap \& Job - det kan lade sig gøre. Strategien bygger videre på strategien: Handicap og job - en beskæftigelsesstrategi for personer med handicap fra 2004.

Danmark har hatt en jobbstrategi siden 2004. Tiltak er gjort, de er evaluert og nye tiltak er utviklet med bakgrunn i ny kunnskap. Det er særlig tre rapporter som er sentrale og som vi refererer til i denne rapporten: Konsulentfirmaet Rambøll leverte ${ }^{9}$ i november 2009 to rapporter vedrørende Evaluering af Handicapindsatsen. En Barriereanalyse og en Løsningskatalog. Formålet med Barriereanalysen var å avdekke barrierer som gjør at personer med funksjonsnedsettelse ikke kommer i jobb samt å undersøke om de arbeidsrettede tiltakene overfor personer med funksjonsnedsettelse er dekkende, tilstrekkelige og relevante. Formålet med

\footnotetext{
8 www.bm.dk

${ }^{9}$ Rapportene ble utført på oppdrag av Beskæftigelsesministeriet i Danmark.
} 
Løsningskatalogen var å peke på løsningsforslag som kan føre til at flere med funksjonsnedsettelse kan komme i jobb.

Det Nationale Forskningscenter for Velfærd (SFI) har evaluert utviklingen mellom 2002 og 2010 i rapporten Handicap og Beskæftigelse (2011). Rapporten har som formål å bidra til foreløpig evaluering også av den siste jobbstrategien fra 2009.

Den nye regjeringen som tiltrådte etter valget i 2011, har annonsert en ny reform av førtidspensjons- og fleksjobsordningen (jobb med lønnstilskudd) i 2012. Grunnelementene i reformutspillet kan leses på Beskæftigelsesministeriets hjemmeside. ${ }^{10}$

\section{Finland}

Regjeringen la i 2010 fram Finlands handikappolitiske program ${ }^{11}$ (20102015). Programmet omfatter 14 ulike forvaltningsområder for politikken overfor personer med funksjonsnedsettelse. Programmet er rettet mot følgende mål:

- Forberede og iverksette de lovendringer som FN-konvensjonen om rettigheter for personer med funksjonsnedsettelse krever.

- Bedre den sosioøkonomiske situasjonen for personer med funksjonsnedsettelse og forebygge fattigdom.

- Sikre tilgang og kvalitet på særskilte tjenester og støttetiltak på ulike områder i landet.

- Øke tilgjengeligheten i samfunnet.

- Styrke handikapforskningen, øke kunnskapsgrunnlaget samt utvikle metodikk som støtte for gjennomføring og oppfølging av handikappolitikken.

Finland undertegnet FN-konvensjonen om rettigheter for personer med funksjonsnedsettelse i mars 2007. I strategien er det rettet særlig oppmerksomhet mot å forberede og iverksette lovendringer som er nødven-

10 www.bm.dk 8. mars 2012 (informasjon lagt ut på hjemmesiden 28.02.12).

11 Ett starkt underlag för delaktighet och jämlikhet. Finlands handikappolitiska program. VAMPO 2010-2015 
dige for ratifisering av FN-konvensjonen om rettigheter for personer med funksjonsnedsettelse.

\section{Island}

Island har utarbeidet et forslag til resolusjon (beslutningsforslag) om politikk og tiltaksplan for personer med funksjonsnedsettelse for perioden 2012-2014.12 Tiltaksplanen er forankret i Lov om funksjonshemmede menneskers anliggender nr. 59/1992 med senere endringer.

Programpolitikken i tiltaksplanen bygger på FN-konvensjonen for personer med funksjonsnedsettelse i tillegg til andre internasjonale menneskerettighetsavtaler som Island har ratifisert. Likestilling og forbud mot forskjellsbehandling på grunn av funksjonsnedsettelse ligger til grunn for tiltaksplanen.

Tiltaksplanen er oppdelt i åtte områder: Tilgjengelighet, arbeidsliv, sosial beskyttelse/selvstendig liv, helse, synlighet og opplysning, likestilling og utdanning.

\section{Norge}

I oktober 2011 la den norske regjeringen fram en ny jobbstrategi ${ }^{13}$ for personer med nedsatt funksjonsevne. Strategien skal omfatte perioden 2012-15. Jobbstrategien er forankret i den politiske plattformen for regjeringen og i trepartsavtalen om et mer inkluderende arbeidsliv (IAavtalen), der en av tre hovedmålsettinger har vært å øke sysselsettingen av personer med funksjonsnedsettelse.

I strategien vises det blant annet til mangel på resultater etter ti års satsing gjennom trepartssamarbeidet om et mer inkluderende arbeidsliv. I andre kvartal 2011 var det ifølge Statistisk sentralbyrå 78000 ikkesysselsatte funksjonshemmede som ønsket arbeid. 22000 av dem var under 30 år. Sysselsettingsnivået for denne gruppen har vært lavt også under gode konjunkturer med stor etterspørsel etter arbeidskraft.

\footnotetext{
12 Island sk utgave ble lagt ut på Velferdsdepartementets hjemmeside - 13. januar 2012.

13 Jobbstrategi for personer med nedsatt funksjonsevne. Vedlegg til Prop. 1S (2011-2012) - Statsbudsjettet 2012 .
} 
I den nye IA-avtalen (2010-13) er det rettet større oppmerksomhet mot å øke sysselsettingen blant personer med nedsatt funksjonsevne.

\section{Sverige}

Den svenske regjeringen presenterte i juni 2011 En strategi för genomförande av funktionshinderspolitiken 2011-2016. Et viktig utgangspunkt for strategien er FN-konvensjonen for rettigheter for personer med funksjonsnedsettelse og konvensjonen for barns rettigheter. Strategien bygger på politikken for personer med funksjonsnedsettelse i den nasjonale handlingsplanen: "Från patient till medborgare" (prop. 1999/2000: 79).

Et sentralt utgangspunkt for strategien er at "funktionshinderpolitiken" er tverrsektoriell og må skje innenfor flere samfunnsområder; arbeidsmarkedspolitikken, sosialpolitikken, utdanningspolitikken, transportpolitikken, IT-politikken, økt fysisk tilgjengelighet, rettsvesenet, folkehelsepolitikken og innen kultur, medier og idrett.

\subsection{Analyse av landenes sysselsettingsstrategier}

Prosjektet sammenligner og analyserer de fem landenes jobbstrategier for personer med funksjonsnedsettelse. Vi ser på fellestrekk og ulikheter i:

- Landenes overordnede prioriteringer og rammer

- Landenes strategiprofil og innsatser

\section{Jobbstrategi eller en strategi som omfatter mange politikkområder}

Finland, Island og Sverige har strategier som omfatter mange politikkområder. Et sentralt utgangspunkt for disse landene er at politikken for personer med funksjonsnedsettelse må skje innenfor flere samfunnsområder. Den finske og svenske strategien er strukturert slik at de har overordnede målsettinger som omfatter alle politikkområdene, deretter kommer delstrategier innenfor hvert enkelt samfunnsområde blant annet innenfor arbeidsmarkedspolitikken. Den islandske strategien er strukturert noe annerledes. Enkelte saksområder omfatter spesifikke politikkområder (for eksempel arbeidsliv, utdanning), mens andre går på tvers av politikkområder (for eksempel synlighet og opplysning). Danmark og Norge har spesifikke jobbstrategier. 
Felles for jobbstrategiene eller delstrategiene som omhandler arbeidsmarkedspolitikken for personer med funksjonsnedsettelse er at de er forankret i det departementet som er ansvarlig for landets arbeidsmarkedspolitikk (sektoransvarsprinsippet).

Alle strategiene vektlegger at personer med funksjonsnedsettelse er en uensartet gruppe med ulike behov og at tiltak må ses i sammenheng på tvers av politikkområder. Det er en politisk målsetting i alle landene at flere politikkområder skal ses i sammenheng.

Alle strategiene, med unntak av den norske jobbstrategien, legger FNkonvensjonen om rettigheter for personer med funksjonsnedsettelse til grunn for sine strategier.

I den finske, islandske og svenske strategien ser vi også en sammenheng mellom oppfølgingen av den nasjonale strategien for personer med funksjonsnedsettelse og oppfølging i forhold til landenes rapportering til FNs overvåkningskomité.

\section{Målgrupper for innsatsene}

Landene har gjort noe ulike valg når det gjelder hvem som er målgruppe for de nærmeste årenes satsinger. De to landene som i størst grad har "spisset" sine innsatser mot utvalgte grupper, er Norge og Sverige.

Den norske jobbstrategien har unge med funksjonsnedsettelse under 30 år som målgruppe. Det skal rettes et særlig fokus på unge i overgangen mellom utdanning og arbeid. Målgruppen består også av personer med nedsatt arbeidsevne som er langtidsmottagere av arbeidsavklaringspenger.

Den svenske jobbstrategien skal øke sysselsettingsgraden for personer med funksjonsnedsettelse som har nedsatt arbeidsevne. Det er også et mål at flere unge under 30 år med funksjonsnedsettelse og nedsatt arbeidsevne får arbeid eller utdanning i perioden.

Danmark, Finland og Island har i sine strategier en mer generell satsing overfor personer med funksjonsnedsettelse. Danmark har dog en satsing på å få flere førtidspensjonister (uføretrygdede) tilbake til arbeidslivet.

I Danmark gis årlige prosjekt- og stimuleringsmidler til både offentlige og private virksomheter overfor utvalgte målgrupper. I disse satsingene er det satt fokus på å fremme sysselsetting for ulike typer funksjonsnedsettelser. 


\section{Overordnede målsettinger}

\section{Konkrete eller generelle målsettinger}

Den danske og islandske strategien har kvantifiserbare målsettinger på hva som skal oppnås i strategiperioden. På Island skal 85 \% av personer med funksjonsnedsettelse ha arbeid, være i aktivitetstiltak eller passende utdanning ultimo 2014. Danmark har konkretisert antall virksomheter som skal ha ansatte med funksjonsnedsettelse, hvor mange flere som skal være trygge med å jobbe sammen med en person med psykiske lidelser og hvor mange førtidspensjonister som skal komme i arbeid etter å ha gjennomført avklaringssamtaler.

De andre landene har som en generell målsetting å øke sysselsettingen for sine målgrupper i strategiperioden.

\section{Flest mulig inn i det ordinære arbeidsmarkedet}

Alle landene understreker i sine strategier at målet er å inkludere personer med funksjonsnedsettelse i det ordinære arbeidsmarkedet. Det finske programmet skisserer deltidsarbeid som en mulighet som ikke i tilstrekkelig grad er utnyttet for å øke inkluderingen i det åpne arbeidsmarkedet. OECDs rapport Sickness, Disability and Work (2011) viser dog at andelen personer med funksjonsnedsettelse som arbeider deltid var påfallende høyere enn for personer uten funksjonsnedsettelse.

\section{Involvering og ansvarliggjøring (eksterne)}

Alle landene har hatt ulike former for involvering av brukerorganisasjoner i prosessen rundt utarbeidelse av strategiene. Enkelte land har hatt mer omfattende prosesser med en bred involvering av for eksempel arbeidsog næringslivet og brukerorganisasjoner, som for eksempel Norge med sine to paneler ${ }^{14}$ eller Finland som gikk bredt ut med mange ulike former for prosesser.

${ }^{14}$ Et erfarings- og idépanel (arbeids- og næringslivet) og et brukerpanel (funksjonshemmedes organisasjoner). 
I Danmark er brukerorganisasjoner i større grad involvert i konkrete initiativer overfor arbeidsgivere og virksomheter. Organisasjonenes innsats har som formål å øke kunnskapen og bygge ned fordommer mot å ansette personer med funksjonsnedsettelse. Brukerorganisasjonene gjøres også medansvarlig i gjennomføring av kampanjer for å motivere ledige med funksjonsnedsettelse til å søke arbeid (for eksempel inspirasjonsm øter om jobbsøking).

\section{Implementering og oppfølging (myndigheter)}

Alle de nordiske regjeringene legger stor vekt på ansvarliggjøring av myndighetene og oppfølging av strategiene. De viser blant annet til utvikling av nye indikatorer som ansvarlige myndigheter skal rapportere på. De fleste landene viser også til at utviklingen skal følges i årene fremover gjennom eksterne evalueringer og undersøkelser i tillegg til oppfølging og rapportering gjennom ansvarlige myndigheter.

Dette vil kunne øke fokus på bedre evalueringer som kan gi bedre evidensbasert kunnskap om arbeidsmarkedspolitiske innsatser overfor personer med funksjonsnedsettelse og bedre kunnskapen om hva som er de mest effektive innsatsene. Det er imidlertid en utfordring i det å innhente statistikk om sysselsettingssituasjonen for personer med funksjonsnedsettelse og sammenligne denne på tvers av landene, da materialet ikke er sammenlignbart.

Norge skal gjennomføre en samfunnsøkonomisk analyse av kostnader og gevinster ved å øke sysselsettingsgraden blant personer med funksjonsnedsettelse som bør være av interesse også for de andre nordiske landene.

\subsection{Konklusjoner}

Vi har forsøkt å belyse forskjeller og likheter mellom landene i valg av tiltak i de nærmeste årene. Hensikten med analysen er at de nordiske landene kan lære av hverandres satsinger og la seg inspirere som grunnlag for videre utvikling av sin arbeids- og sosialpolitikk. Vi vil her sammenfatte hovedfunnene våre. 
De nordiske landene har valgt to hovedinnretninger på sine arbeidsmarkedspolitiske strategier for personer med funksjonsnedsettelse. I Finland, Island og Sverige håndteres den arbeidsmarkedspolitiske strategien for personer med funksjonsnedsettelse som ett av flere politikkområder. Danmark og Norge har spesifikke jobbstrategier.

Alle strategiene, med unntak av den norske, tar utgangspunkt i FNkonvensjonen for personer med funksjonsnedsettelse. Alle strategiene har som mål at flest mulig skal inn i det ordinære arbeidsmarkedet. Danmark og Island konkretiserer sine målsettinger i langt større grad enn de andre landene. Norge og Sverige retter sine tiltak mot utvalgte målgrupper blant personer med funksjonsnedsettelse.

Når det gjelder strategiprofil og valg av innsatser viser gjennomgangen at tiltakene i stor grad rettes mot enkeltpersoner, det vil si arbeidssøkere eller arbeidstakere, hva enten de trenger lite eller mye bistand for å komme i arbeid eller tilbake i arbeid. Dette er tiltak orientert mot tilbudssiden i arbeidsmarkedet og i tråd med den arbeidsmarkedspolitikken som i stor grad har vært ført i de nordiske landene. Noen tiltak har som formål å kompensere for arbeidsgivers ekstrautgifter ved å ansette personer med funksjonsnedsettelse. Andre tiltak har som formål å styrke enkeltpersoners muligheter til å prøve seg på arbeidsmarkedet og/eller redusere arbeidsgivers usikkerhet og frykt for merarbeid gjennom en styrking av ulike former for oppfølgingstiltak.

Det må imidlertid påpekes at strategiene fortrinnsvis beskriver nye tiltak og satsingsområder for strategiperioden. Strategiene gir derfor ikke et fullgodt bilde av det enkelte lands arbeidsmarkedspolitiske satsinger. Strategiene må derfor ses i lys av de innsatser de ulike regjeringene har sett behov for å supplere i forhold til allerede eksisterende tiltak.

Alle landene har tiltak som skal øke kompetansen i hjelpeapparatet for å kunne gi en bedre og mer målrettet tjeneste overfor personer med funksjonsnedsettelse og virksomheter. Norge og Sverige har i tillegg en ressursmessig styrking av hjelpeapparatet for å øke innsatsen for å få flere med funksjonsnedsettelse i arbeid.

Det er i hovedsak Norge som videreutvikler ordninger for arbeidss $\varnothing$ kere som har til hensikt å kompensere for arbeidsgivers ekstrautgifter. I den finske strategien foreslår man å utrede enkeltordninger med dette som formål. 
Danmark har på bakgrunn av en evaluering valgt å videreføre og styrke eksisterende ordninger. Også Sverige har styrket eksisterende ordninger.

Både den islandske, norske og svenske strategien viser til nye tiltak som skal styrke enkeltpersoners muligheter til å prøve seg på arbeidsmarkedet. Kun den islandske strategien viser til en viss strategisk satsing på teknologisektoren for å utvikle og styrke jobbmulighetene for personer med funksjonsnedsettelse. Både den norske og svenske strategien viser til nye oppfølgingstiltak på arbeidsplassen. Oppfølging på arbeidsplassen kan ha som formål å bidra til økt trygghet og redusere risiko for både arbeidssøker og arbeidsgiver.

Alle strategiene viser til at det offentlige (kommuner og/eller staten) har et særlig ansvar for å sysselsette flere med funksjonsnedsettelse. Både den norske og svenske strategien viser til igangsettelse av praktikant- og traineeprogram i statlige virksomheter. Den islandske strategien fokuserer på å skape nye jobbmuligheter i et samarbeid mellom arbeids- og næringslivet og myndighetene. Danmark stimulerer blant annet offentlige og private virksomheter til deltakelse i utviklings- og modellprosjekter som skal fremme sysselsetting for personer med funksjonsnedsettelse. Sverige har blant annet utarbeidet en handlingsplan for arbeidsinkluderende sosiale virksomheter.

Reguleringspolitiske tiltak som er særlig rettet mot etterspørselssiden i arbeidsmarkedet, det vil si mot arbeidsgivere og virksomheter, består i stor grad av informasjons- og holdningsskapende aktiviteter for at disse skal ta et større frivillig ansvar for å inkludere flere med funksjonsnedsettelse.

Alle strategiene har ulike tiltak i form av informasjons- og holdningsskapende aktiviteter rettet mot arbeidsgiverne. Danmark har en særlig satsing på holdningsskapende aktiviteter, ikke bare overfor arbeidsgiverne, men også overfor personer med funksjonsnedsettelse. Danmark trekker brukerorganisasjonene i større grad med i de holdningsskapende aktivitetene enn andre land. Island har synlighet og opplysning som et overordnet innsatsområde. Sverige skal lage en oversikt over effektive metoder for holdningspåvirkning innom arbeidslivet. 
Strategiene har lite fokus på reguleringspolitiske virkemidler i form av økte lovkrav overfor arbeidslivet. Alle strategiene understreker betydningen av å redusere samfunnsskapte barrierer for å øke inkludering av personer med funksjonsnedsettelse. Strategiene inneholder imidlertid ikke en strategisk satsing i form av økte krav til universell utforming i arbeidslivet.

Alle de nordiske regjeringene vektlegger ansvarliggjøring av myndigheter i gjennomføring og oppfølging av strategiene. De fleste landene skal i tillegg følge utviklingen gjennom eksterne evalueringer og undersøkelser.

Norge skal gjennomføre en samfunnsøkonomisk analyse av kostnader og gevinster ved å øke sysselsettingsgraden blant personer med funksjonsnedsettelse.

Manglende inkludering av personer med funksjonsnedsettelse er en felles nordisk utfordring. Bedre evalueringer, utveksling av erfaring og resultater samt mer systematisk kunnskap på nasjonalt og nordisk nivå vil kunne bidra til å utvikle arbeidsmarkedspolitikken for personer med funksjonsnedsettelse.

\section{Kilder og referanser}

For kilder og referanser, se hovedrapporten Et arbeidsmarked for alle? 


\subsection{Figur- og tabellvedlegg - Et arbeidsmarked for alle?}

\section{Høy forekomst av funksjonshemmede i arbeidsfør alder i OECD-landene}

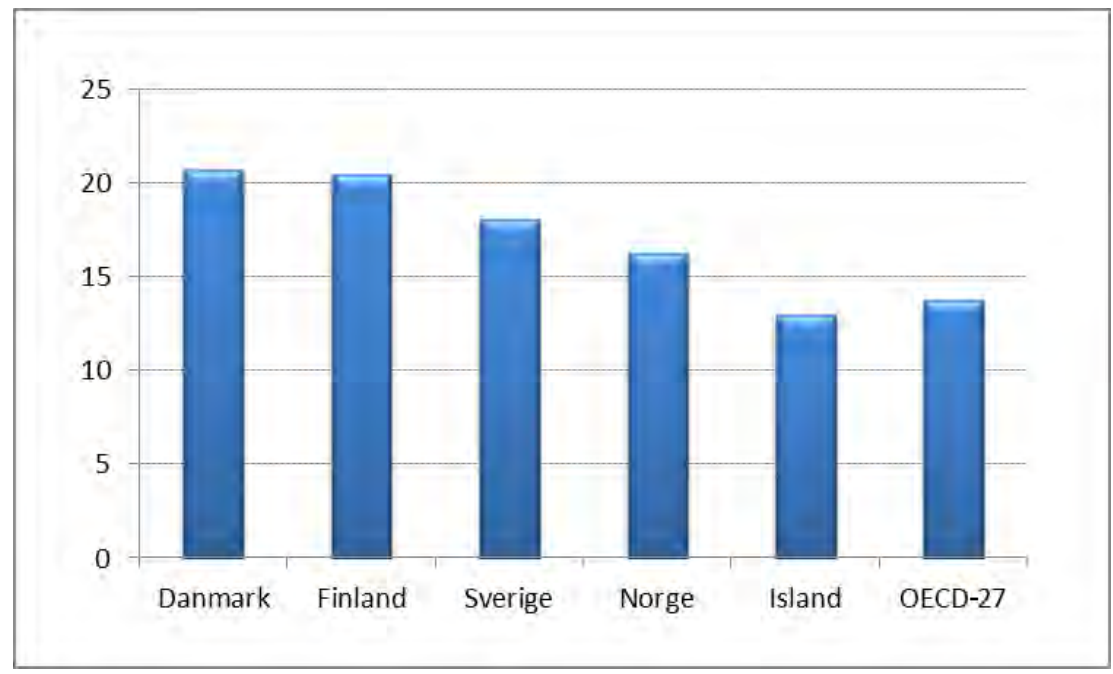

Egenvurdert forekomst av funksjonshemning, som andel i prosent av befolkningen 20-64 år, mot slutten av det første tiåret på 2000-tallet. OECD-27 er et uvektet gjennomsnittstall for 27 land. Estland og Slovenia var ikke inkludert i OECD-gjennomsnittet.

Kilde: Sickness, Disability and Work (OECD 2010). Figur 1.1 Disability prevalence at working age is high in most OECD countries. Datagrunnlaget kommer i første rekke fra EU SILC ${ }^{15} 2007$. For Danmark og Norge er grunnlagsmaterialet hentet fra AKUs tilleggsunders $\varnothing$ kelse i 2005.

${ }_{15}^{15}$ EU-SILC eller bare SILC (EU Statistics on Income and Living Conditions) er en undersøkelse med systematisk sammenligning av data fra landvise unders $ø$ kelser i EU, Island, Sveits, Norge og Tyrkia. 


\section{Lav sysselsetting blant personer med nedsatt funksjonsevne i alle land}

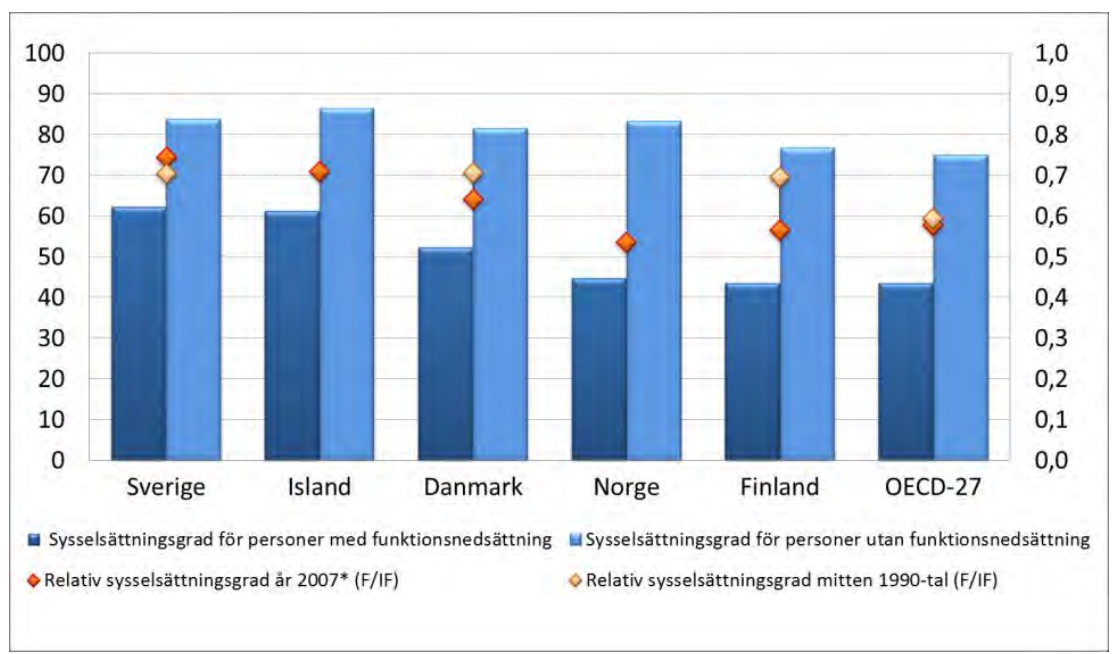

Sysselsettingsgrad for personer med nedsatt /ikke nedsatt funksjonsevne på slutten av det første tiåret på 2000-tallet (den venstre aksen). Relativ sysselsettingsgrad (den høyre aksen) for personer med nedsatt funksjonsevne sammenlignet med personer uten nedsatt funksjonsevne på midten av 1990-tallet og slutten av det første tiåret på 2000-tallet.

Kilde: Sickness, Disability and Work (OECD 2010). Figur 2.1 Employment rates of people with disability are low and have been falling in many countries. Dataene er fra EU SILC-unders $\varnothing$ kelsen i 2007 eller siste måling før 2007, for Danmark og Norge er grunnlagsmaterialet hentet fra AKUs tilleggsunders økelse i 2005.

I Sverige blir personer med funksjonsnedsettelse delt opp i to kategorier: De som har nedsatt arbeidsevne og de som ikke har det. For personer med funksjonsnedsettelse og uten nedsatt arbeidsevne ligger sysselsettingen svært nær sysselsettingsnivåt for befolkningen generelt, og det er til og med målt et litt høyere sysselsettingsnivå for denne gruppen. Dette innebærer også at personer med funksjonsnedsettelse og nedsatt arbeidsevne har en enda vanskeligere situasjon på arbeidsmarkedet enn det som framgår av OECDs sammenligning. 


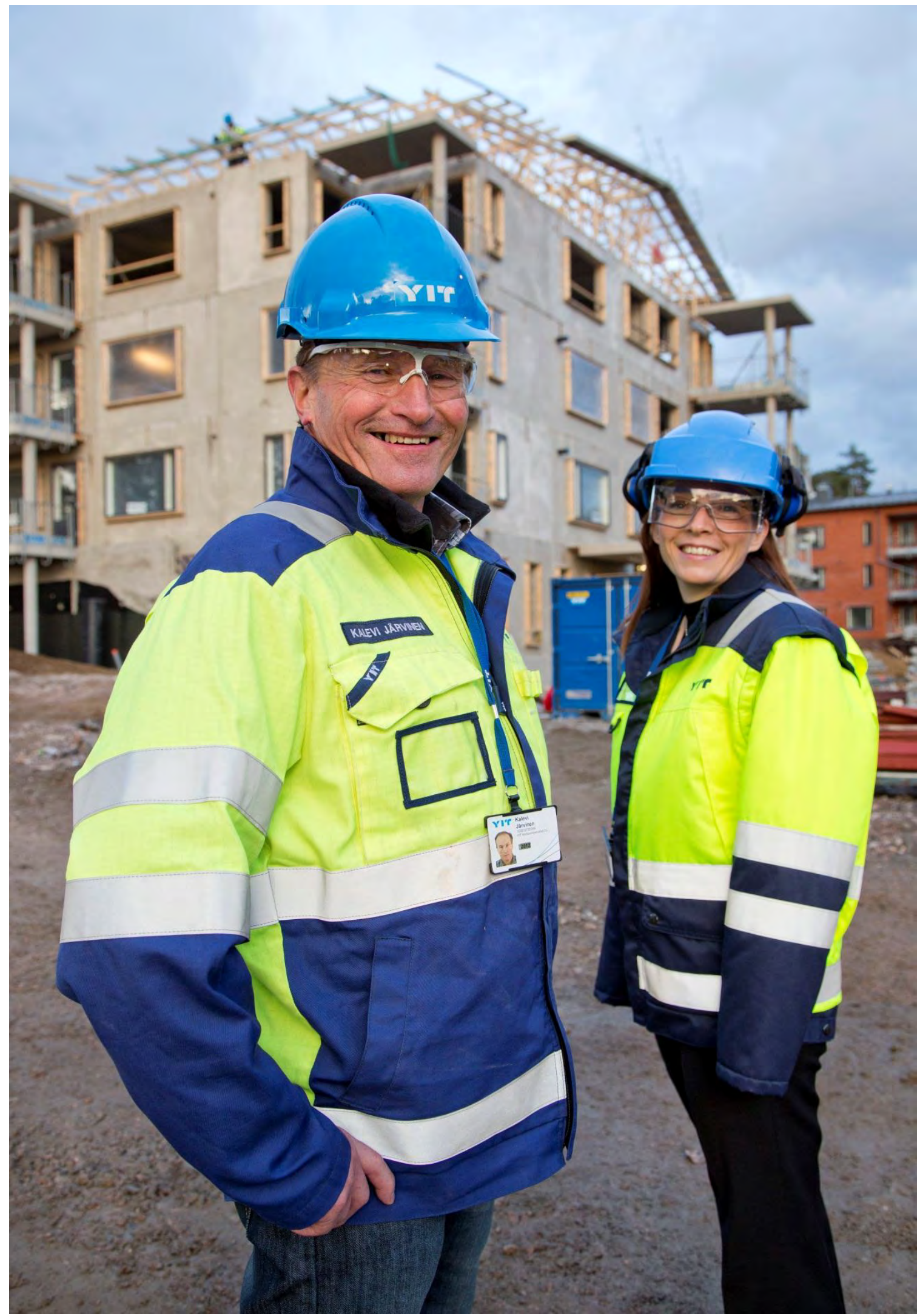




\section{Det dreier seg om helse og arbeidsglede. Om seniorer, arbeid og pensjonering $\mathbf{i}$ Norden}

Denne rapporten handler om seniorer $i$ arbeidslivet i de nordiske landene, om deres deltakelse i arbeidslivet og hovedveier ut av arbeidslivet. Rapporten beskriver hva som gjøres og oppnås for at flest mulig seniorer kan fortsette flere år i arbeid, dersom de ønsker det og har helse til det. Dette er under forutsetning av at man fortsatt har og skal ha gode pensjonsordninger og sosiale sikkerhetsnett ellers for hele befolkningen.

Senior defineres i denne sammenheng som personer mellom 50 og 70 år. Rapporten ser først og fremst på seniorer som er i eller har hatt et varig arbeidsforhold. Innen aldersspennet 50-70 år fokuseres det mest på aldersgruppen mellom cirka 55-65 år, fordi det i denne fasen avgangen fra arbeidslivet er størst.

\subsection{Konklusjoner}

\section{Aldrende befolkning, men også mange barn}

Som Europa for øvrig har de nordiske landene aldrende befolkninger. Det vil si at levealderen i befolkningen øker og at det blir en større andel eldre i befolkningen. Dette er fortsettelse av en lang historisk utvikling med bedre helse og velferd for stadig flere. Den demografiske hovedutfordringen i Europa er at det fødes for få barn til å opprettholde en stabil befolkningssammensetning over tid. Samtidig har tendensen i mange år vært at seniorer går tidlig ut av arbeidslivet og at unge kommer senere inn i arbeidslivet enn før. Dette skaper utfordringer med hensyn til fordelingen 
av goder og byrder mellom generasjonene. De nordiske landene står relativt godt rustet, med høy deltakelse i arbeidslivet - også blant seniorer og med relativt høye fødselsrater i befolkningen sammenlignet med de fleste andre land i Europa.

\section{Høy stabil deltakelse i arbeidslivet, men også mange utenfor}

De nordiske landene har høy grad av deltakelse i arbeidslivet sammenlignet med de fleste andre land. Dette er hovedgrunnen for vår høye materielle velstand og velferd og for den betydelige likheten som kjennetegner de nordiske landene og folkene. Ikke minst blant seniorer fra om lag 50 år og eldre er deltakelsen i arbeidslivet relativt høy i Norden. Men det er også betydelige forskjeller - både mellom og innen de nordiske landene. Det at mange er i arbeidslivet og få blir forsørget av ektefelle, bidrar også til at mange mottar sosiale inntektssikringsytelser fra tid til annen eller mer permanent. Ungdomsarbeidsløshet og tendenser til ungt utenforskap er også en utfordring i flere av de nordiske landene. Mange med funksjonsnedsettelse møter hindringer og problemer med å få innpass og fotfeste i arbeidsmarkedet. Det samme gjelder personer med flyktninge- og innvandrerbakgrunn. Mange seniorer går tidlig ut av arbeidslivet, ofte allerede i 50-årsalderen. Det er også store regionale forskjeller når det gjelder deltakelse i arbeidslivet og utenforskap innen de nordiske landene.

\section{Seniorer har ikke måttet vike for yngre i arbeidslivet}

Det er ikke tegn nå til det som skjedde ved den store økonomiske krisen for cirka 20 år siden: Nemlig at mange seniorer gikk tidlig ut av arbeidslivet og at nye former for førtidspensjonsordninger ble innført, blant annet for å gi plass til unge arbeidsledige. Dette ga insitamenter til tidlig avgang fra arbeidslivet. Isteden har politikken har denne gangen vært å møte den økonomiske krisen ved motkonjunkturtiltak på kort sikt, kombinert med mål om høy deltakelse og inkludering også av utsatte grupper i arbeidslivet. Dette har man til dels lyktes ganske bra med i Norden. En utfordring nå er høy og til dels vedvarende ungdomsledighet og et alarmerende utenforskap blant unge i flere av landene, også i Norden. 


\section{Seniorers hovedveier ut av arbeidslivet er i hovedsak:}

- Redusert helse og arbeidsevne; langtids sykefravær og førtidspensjon fra om lag 50-årsalderen ("uhelseveien").

- Fleksibelt og valgfritt uttak av alderspensjon mellom cirka 60-70 år ("fritidsveien").

- Langtidsarbeidsledighet, store omstillinger og nedbemanninger i arbeidslivet ("utstøtingsveien").

- Stengsler: Aldersgrenser, diskriminering, uvitenhet og fordommer ("stengselsveien").

Den store "utfartsveien" fra arbeidslivet er av helsemessige årsaker og via varig sykefravær og uførepensjonering/førtidspensjonering allerede i 50årsalderen. Den andre hovedveien er individuell, selvvalgt og fleksibelt uttak av alderspensjon i 60-årene. Den tredje hovedveien har mer bakgrunn i forhold i arbeidslivet og arbeidsplassen: Arbeidsmiljø og ledelse så vel som store omstillinger og nedleggelser. En fjerde hovedvei kommer som følge av formelle og uformelle stengsler når det gjelder aldersgrenser, uvitenhet, fordommer og diskriminering. Ofte virker flere av disse faktorene og hovedveiene sammen og forsterker hverandre.

De strategiene og virkemidlene som skal motvirke uønsket tidlig avgang fra arbeidslivet og heller fremme deltakelse i arbeidslivet i flere år må ta hensyn til at disse hovedveiene og drivkreftene som ligger bak, er forskjellige. Det er også stor forskjell om det er tale om henholdsvis fastholdelse i jobben, å komme tilbake i jobben etter fravær eller rekruttering i ny jobb. Se mer om dette figur- og tabellvedlegget og i hovedrapporten.

\section{Økonomisk politikk og velferdspolitikk med vekt på arbeid, likhet og sosial trygghet}

Det er avgjørende for en bærekraftig velferd at det føres en økonomisk politikk med sikte på høy deltakelse i arbeidslivet i hele den voksne befolkningen. Videre at det samtidig legges vekt på at det skal være en god, sosial trygghet for alle ved bortfall av arbeidsinntekt og en balanse av goder og byrder i befolkningen over tid. Høy deltakelse i arbeidslivet blant seniorer er et viktig element i dette. Det viktigste grunnlaget for framtidig velferd er som det alltid har vært: barn, oppvekstsvilkår, utdanning og kunnskap, arbeid, likhet og folkehelse. Fungerer dette bra, har man også 
grunnleggende tillit og tør å ta sjanser med å utvikle nye og bedre ting, selv om det kan være forbundet med risiko.

\section{Arbeidsmarkedsstrategier}

Arbeidsmarkedspolitikken og dens virkemidler er i de nordiske landene i hovedsak rettet mot hele den voksne befolkningen. Den er i liten grad delt opp i eller skreddersydd til bestemte målgrupper, som unge, seniorer, kvinner osv. Virkemidler og tiltak settes inn individuelt, tilpasset den enkeltes situasjon, ressurser og utfordringer. Samtidig prioriteres visse utsatte grupper på arbeidsmarkedet, slik som ungdom, innvandrere og langtidsledige, herunder mange seniorer. I enkelte av de nordiske landene (f.eks. Danmark) og i enkelte situasjoner (store omstillinger) er det eksempler på at en har gått lengre i å målrette og skreddersy innsatsen. Det er neppe hensiktsmessig å tenke enten universelle løsninger eller målretting, men heller søke å finne fram til gode blandingsforhold som er effektive og gir resultater. Kompetanse og livslang læring kan med fordel få mer plass i seniorpolitikken.

\section{Pensjonsreformer og aldersgrenser}

Samtlige nordiske land unntatt Island har gjennomført eller er i ferd med å gjennomføre omfattende pensjonsreformer. Et viktig mål er å bidra til å øke tilbudet av arbeid blant seniorer, slik at flere fortsetter lengre i arbeid. Samtidig åpnes det for større individuell valgfrihet med hensyn til pensjoneringsalder og mer fleksibel adgang til å kombinere delpensjon og deltidsarbeid. I flere land vurderes det også å oppheve eller heve aldersgrensene for når man kan sies opp på grunn av alder. Dette synes som en naturlig konsekvens over tid, selv om det også kan gi utfordringer. De samlede virkningene av disse reformene er ennå usikre, både fordi reformene er nye og fordi ulike faktorer og drivkrefter kan trekke i ulike retninger. Det er viktig med god evaluering av resultater og effekter av reformene i forhold til de grunnleggende formålene, slik at en kan justere om nødvendig.

\section{Reformer $\mathrm{i}$ andre sosialforsikringer}

I flere av de nordiske landene pågår det også reformer i andre deler sosialforsikringssystemet. Målet er å motvirke og redusere utenforskap av helsemessige grunner eller langtidsarbeidsledighet. Ikke minst er det eller blir det i flere av landene iverksatt og gjennomført reformer innen sykeforsikring, rehabilitering og arbeidsmarkedsinnsatser for mer utsatte 
grupper på arbeidsmarkedet. Det er også viktig at disse reformene følges nært og godt opp med god resultatrapportering og evaluering. Det offentlige styringssystemet kan i mange tilfeller og med fordel bli mer opptatt av resultater og gode resultatindikatorer enn av omfattende og detaljert rapportering om aktiviteter.

\section{Informasjon, påvirke holdninger, motvirke diskriminering}

Alle nordiske landene har innsatser for å motvirke diskriminering, usikkerhet og fordommer knyttet til eldre arbeidskraft, både gjennom lovgivning, informasjon og påvirkning. I Norge pågår det for eksempel som ledd i trepartssamarbeidet om et inkluderende arbeidsliv et virkningsfullt informasjons- og påvirkningsarbeid gjennom "Senter for seniorpolitikk." På Island har seniorer og eldre tradisjonelt vært høyt verdsatt og respektert og mye brukt.

\section{Seniorpolitikk på virksomhetsplan}

Mye av de seniorpolitiske innsatsene på virksomhetsplan er primært rettet mot seniorer i begynnelsen av 60-årene. Det dreier seg da ofte om arbeidstid, fritid, lønn og pensjon: I noen tilfeller handler det også om forebyggende helsemessig tilrettelegging og tilpasning i forhold til redusert helse. Det framgår at mye av dette er nokså likt utformet, både mellom bedrifter og innen bedrifter ("one-size-fits all"). Dette til tross for at jobbene kan være forskjellige, seniorene er forskjellige, helsen og kompetansen forskjellig osv. Mye av denne innsatsen kan synes å ha liten effekt. Seniorene setter pris på det, ikke minst dersom det gir uttrykk for at de blir verdsatt. Men innsatsene har karakter av goder for dem som likevel ville fortsette. Noen "god praksis"-eksempler har mer av en "vinn-vinnvinn"-karakter for både seniorene, bedriften og samfunnet. Det vil si at man satser på seniorene som ressurser - fordi det er smart og lønnsomt for virksomheten. Seniorpolitikken kan da være ledd i en god, samlet ledelses- og livsfasepolitikk for å fremme gode virksomheter og konkurransedyktige produkter og leveranser. Det framgår at mye av seniorinnsatsen ikke eller i liten grad er evaluert. 


\section{Arbeidsmiljø og ledelse er avgjørende}

Arbeidsmiljø og ledelse er avgjørende både når det gjelder tilknytning til jobben, men også tiltrekning mot pensjon og/eller alternativ virksomhet. Dette gjelder både helsemessige og sosiale sider av arbeidslivet, så vel som type jobb, oppgaver, utfordringer, kompetanse og ikke minst det å bli verdsatt. Med andre ord: Det dreier seg om ledelse og om kolleger og forholdet mellom mennesker på jobben. I noen grad og tilfeller kan det dreie seg om å tilpasse det fysiske arbeidsmiljøet og arbeidsoppgavene til at seniorer kan ha/få svekket helse med alderen. Men det dreier seg også om det mentale og sosiale arbeidsmiljøet: Stadig flere seniorer er kommet og kommer i den situasjonen at de kan velge pensjon, annet arbeid eller annen virksomhet, dersom de ikke trives på jobben og føler seg brukt og verdsatt. Klok og god ledelse tar høyde for dette og sørger for mangfold på arbeidsplassen. Virksomheter som får til et godt fungerende mangfold i arbeidsstokken er antakelig framtidas vinnere i den globale konkurransen.

\subsection{Anbefalinger}

\section{Flere i arbeid er avgjørende for bærekraftig velferd}

Høy deltakelse i arbeidslivet i alle deler av den voksne befolkningen er avgjørende for en holdbar velferd med god fordeling av goder og byrder i befolkningen over tid. Derfor er det også viktig at flere seniorer kan fortsette lengre tid $i$ arbeid.

\section{Brede strategier og løsninger er nødvendig}

Seniorpolitikk må dreie seg om langt mer enn fritid og pensjon for folk i 60 -årsalderen. Det bør dreie seg om insentiver og virkemidler i samfunnsøkonomien, arbeidsmarkedet og det sosiale sikkerhetsnettet som gjør arbeid lønnsomt både for arbeidstakere, arbeidsgivere og samfunnet. Det dreier seg da om arbeidsmiljø, ledelse og folkehelse. Det dreier seg også om informasjon og påvirkning av holdninger og diskriminering og ikke minst hvordan alt dette kan fungere best mulig sammen. 


\section{Seniorpolitikken bør satse mer og tidligere på helse og arbeidsmiljø}

Den store utfarten fra arbeidslivet har bakgrunn i dårlig helse og arbeidsmiljø, og den starter i 50-årsalderen. Forebyggende strategier bør ta tak i dette. Innsatsene bør reflektere bedre hva som er viktige årsaker og drivkrefter bak tidlig og uønsket avgang fra arbeidslivet blant seniorer. Arbeidsmiljø og helse er avgjørende for å forebygge sykefravær og uførepensjonering. Det handler om å gjøre arbeidsplassen helsevennlig og helsefremmende. Forebygging og tilrettelegging er viktig, så vel i virksomheten som helhet som overfor enkeltpersoner med helserisiko og redusert helse. Forebygging og tilrettelegging må være konkret, tilpasset virksomheten, arbeidsstokken og individet.

\section{Både universelle og målrettede løsninger er nødvendig}

Mye av seniorpolitikken er utformet likt for alle; en "one-size-fits-all"tilnærming. Dette er neppe effektivt. Samtidig skal en verne og bygge på viktige likhetsprinsipper. Utfordringen er å finne gode kombinasjoner av både universelle og målrettede innsatser ("folkedress" og "skreddersøm").

\section{Oppheve eller heve aldersgrensene i arbeidslivet}

Som en oppfølging av pensjonsreformene bør man fjerne eller heve dagens regler om generelle og særskilte aldersgrenser der folk kan sies opp eller må gå av ved bestemte aldre. Slikt er ikke forenlig med målet om flere seniorer lengre i arbeid og med pensjonsreformene på lengre sikt. Dette forutsetter en god livsløpsledelse, der blant annet jevnlige medarbeidersamtaler får en viktig plass og reelt innhold og oppfølging.

\section{Satse på mangfold i arbeidsstyrken}

De forestillingene og normene om hvem som "hører naturlig til" på arbeidsplassene er i stadig endring. Dagens ledelsesidealer peker mot å utvikle kompetanser og tilrettelegge for å ta i bruk ressurser og kunnskap som gir en mangfoldig arbeidsstyrke. Dette handler om å utvikle organisasjoner som gir rom og "takhøyde" for menneskelig forskjellighet, variasjo- 
ner i ideer og verdier og ta disse ressursene aktivt i bruk. Slik variasjon kan være språk, kompetanse, kjønn, etnisk bakgrunn - og alder. Det dreier seg om å ivareta den enkeltes interesser, ønsker og behov slik at arbeidsplassen oppleves som meningsfull, interessant og utfordrende. For arbeidsplassen som organisasjon handler det om å ta vare på og utnytte de ressursene som ligger hos den enkelte medarbeider og i fellesskapet.

\section{Satse på seniorer som ressurser og på livslang læring}

Det avgjørende for å bli i jobb er at en blir sett, brukt og verdsatt. Ansvaret for å ta i bruk seniorenes kompetanse ligger på den enkelte leder. Det er sløsing å ikke bruke seniorenes ressurser eller å bruke dem feil. For å beholde seniorenes attraktivitet og relevans som arbeidskraft er det av stor betydning at også seniorene har tilgang til å delta i kompetansehevende tiltak på linje med øvrige arbeidstakere. Det dreier seg eksempelvis om mulighet til faglig oppdatering, deltakelse på kurs, delta $\mathrm{i}$ utviklingsprosjekter, tid til videreutvikling - av den typen kunnskap og ferdigheter som er relevant for organisasjonen.

\section{Lære av naboen}

Det pågår mange og gode seniorpolitiske innsatser i de nordiske landene, og de samlede resultatene er overveiende gode. Det er likevel interessante forskjeller både i utforming, gjennomføring og resultater. Det gjelder både på nasjonalt nivå og virksomhetsnivå. De nordiske landene er samtidig nokså like i grunnleggende verdier og institusjoner. Det gjør det fruktbart å bli inspirert av hverandre og å lære av hverandre. Denne rapporten kan bidra til dette.

\section{Vi foreslår en komparativ evaluering av pensjonsreformene i Norden}

Så og si alle de nordiske landene har reformert eller er i ferd med å reformere pensjonssystemene sine. NVC mener det kan være en god idé med komparativ nordisk evaluering i tillegg til de nasjonale. Reformene bør evalueres opp 
mot de grunnleggende målene om deltakelse i arbeidslivet, økonomisk trygghet, likhet og sosial omfordeling. Ikke bare ett av dem, men alle.

\subsection{Hva gjøres? Om politikk, programmer og innsatser}

\section{Mål og strategier for bærekraftige, aldrende samfunn}

Samtlige nordiske land har som en viktig del av sin økonomi- og velferdspolitikk å opprettholde en god balanse av ytelser og byrder mellom generasjonene på lang sikt. En viktig del av denne politikken er strategier for å opprettholde og helst øke yrkesdeltakelsen blant seniorer og å få flere seniorer til å fortsette lengre i arbeid dersom de har helse til det. En del av slike strategier er også å utvikle større individuell valgfrihet og mer fleksible løsninger i overgangene mellom arbeid og pensjonering. Reformer i pensjonssystemene er sentrale elementer i en slik strategi. Ingen nordiske land har nå som erklært politikk å førtidspensjonere seniorer for å bidra til reduksjon av ungdomsarbeidsløsheten, slik det til en viss grad skjedde ved de økonomiske krisene rundt 1990.

Danmark har gjort mange grep for å holde orden i de offentlige finansene og for å styrke produksjon og deltakelse i arbeidslivet. Det er blant annet gjennomført reformer i "efterlønsordningen," en velferdsreform (2006), en Job-Plan (2008), pensjonsalderreformer (2011) og nå sist "innsatspakke" for å bedre muligheten for at seniorer skal kunne fortsette i arbeidslivet (2012). Finland har også lagt stor vekt på å holde orden $\mathrm{i}$ $\varnothing$ konomien og å styrke deltakelsen i arbeidslivet. Regjeringen (Katainen) satt seg som konkret mål å øke den gjennomsnittlige yrkeskarrieren med tre år innen 2020. En samlet arbeids- og sysselsettingsstrategi er lagt fram av Arbeids- og næringsdepartementet og en nasjonal aldringsstrategi er lagt fram av Social- og helsedepartementet (2008).

Island hadde den største kollapsen i økonomien, men ser ut til å komme seg godt ut av krisen igjen. Landet har en relativt ung befolkning og svært høy yrkesdeltakelse blant eldre. Pensjonsalderen er høy, det er lang opptjeningstid for full pensjon, og offentlige pensjoner er relativt lave. Det er ingen eksplisitt politikk om å øke yrkesdeltakelsen og reell avgangsalder på Island. Ungdomsarbeidsløsheten har prioritet. 
I Norge er det et tydelig og høyt prioritert mål å ha god balanse i nasjonaløkonomien og offentlig økonomi både på kort og lang sikt. Aktiv motkonjunkturpolitikk på kort sikt kombineres med en langsiktig stabiliseringspolitikk med vekt på bærekraftig velferd og generasjonsbalanse. Pensjonsreformer og trepartssamarbeid om et inkluderende arbeidsliv er viktige strategier og reformer.

I Sverige har god balanse i de offentlige budsjettene stått svært sentralt. Reformer i syke- og førtidspensjon har hatt som mål å redusere "utfart" fra arbeidslivet via slike sosiale forsikringer. Det er også regjeringens ambisjon at flere seniorer skal arbeide lengre, også etter fylte 65 år. Pensionsåldersutredningen (SOU 2012:28) har lagt fram omfattende strategier og forslag for hvordan man skal få dette til. Utredningen har nylig fått et tilleggsdirektiv om oversyn av pensjonsrelaterte aldersgrenser og muligheter for et lengre arbeidsliv.

\section{Arbeidsmarkeds- og arbeidsmiljøstrategier}

Arbeidsmarkedspolitikken retter seg i hovedsak mot hele den voksne befolkningen i de nordiske landene. Tiltakene er i stor grad felles for alle aldersgrupper og søkes tilpasset det enkelte individs utfordringer og forutsetninger, uavhengig av alder. Samtidig er visse grupper prioritert, slik som ungdom, langtidsarbeidsledige og innvandrere. Seniorer finner man ofte blant de langtidsledige. I Danmark og Sverige kan man nå se en tendens til mer skreddersydde løsninger for og blant seniorer i tillegg til de mer generelle arbeidsmarkedsinnsatsene. Det er også en del interessante forskjeller landene imellom når det gjelder innretningen på kompetansetiltak og livslang læring. Aldersgrenser - den alder der man kan sies opp på grunn av alder alene - er som regel forankret i arbeidsmiljølovgivningen samt i særlover for bestemte yrkesgrupper. I kjølvannet av pensjonsreformer diskuteres nå tilpasninger av aldersgrenser.

I Danmark har en foreløpig gått lengst i å øke eller fjerne aldersgrenser. Skiftende regjeringer har også lagt fram diverse reformer og handlingspakker på dette området: Job Plan (2008) og Arbeidsmarkedskommisjonen (2009). Det er gjort omfattende reformer i ordningene for etterlønn, fleksjobb, førtidspensjon, beskjeftigelsesinnsats, rehabilitering, aldersgrenser og skatt. Alle har til formål å øke og forlenge yrkesdeltakelsen blant seniorer. 
I Finland satses det mye på arbeidsmiljøspørsmål og -tiltak, også når det gjelder aldring og eldre. Det synes ikke å være tilsvarende seniorperspektiv i arbeidsmarkedspolitikken, men livslang læring er en viktig og prioritert del av utdannings- og arbeidspolitikken.

Island har som sagt ikke eller få arbeidsmarkedsinnsatser spesielt rettet mot seniorer, men livslang læring er en viktig del av utdanningssystemet, og mange seniorer deltar i dette.

I Norge utgjør trepartssamarbeidet om et Inkluderende Arbeidsliv (IA) den sentrale strategien. Delmål 3 i IA-avtalen går ut på å øke den gjennomsnittlige avgangsalderen i arbeidslivet. Avgangsalderen økte på 2000tallet fram til 2009, deretter har den har gått litt ned igjen.

I Sverige har regjeringen utarbeidet en handlingsplan for arbeidsmiljøpolitikken for årene 2010-2015. Ambisjonen er at arbeidsmiljøet skal bidra til å bryte utenforskap og motvirke utstøtning fra arbeidsmarkedet. Det er også gjennomført diverse arbeidsmarkedstiltak, blant annet gjennom "Lag om anställningsskydd" (LAS) for å bidra til at eldre fortsetter lengre i arbeid.

\section{Pensjonsreformer og aldersgrenser}

Samtlige nordiske land unntatt Island har gjennomført eller er i ferd med å gjennomføre omfattende pensjonsreformer. Et viktig mål er å bidra til å $\varnothing \mathrm{ke}$ tilbudet av arbeid blant seniorer, slik at flere fortsetter lengre i arbeid. Samtidig åpnes det for større individuell valgfrihet med hensyn til pensjoneringsalder og mer fleksibel adgang til å kombinere delpensjon og deltidsarbeid. Flere land diskuterer eller endrer samtidig aldersgrensene for når man kan sies opp på grunn av alder.

I Danmark har regjeringen og to politiske partier inngått en avtale om en pensjoneringsalderreform. Målet er å trappe opp pensjons- og etterlønnsalderen med fem år innen 2022/2023. Den formelle pensjonsalderen skal økes gradvis fra 65 til 67 år mellom 2019 og 2022, og etterlønnsalderen økes fra 60 til 62 år mellom 2014 og 2017. Det er også lagt fram forslag om reform av førtidspensjonen og fleksjobbordningen for å motvirke utenforskap og ekskludering fra arbeidslivet.

I Finland er pensjonssystemet reformert med virkning fra 2005. Blant annet er det innført mer fleksibel pensjoneringsalder og en levealdersindeksering av opptjente pensjoner. 
På Island er det fra 2007 innført utvidet adgang til å utsette pensjonsuttaket etter pensjonsalderen på 67 år, slik at en får høyere opptjening ved senere uttak.

I Norge gjennomføres det en omfattende alderspensjonsreform med gradvis iverksetting fra 2011. Levealdersindeksering av opptjente pensjoner, adgang til mer fleksibelt, men kostnadsnøytralt uttak av pensjon og en meget liberal adgang til å kombinere pensjon og arbeidsinntekter er viktige elementer. Det gjennomføres også tilpasninger og reformer i uførepensjonen (førtidspensjon ved helsesvikt).

Sverige reformerte den allmenne alderspensjonen allerede med gradvis virkning fra 1999. Hovedelementene er også levealdersindeksering og mer valgfri og fleksibel pensjoneringsadgang, basert på kostnadsnøytralitet. Det gir insentiver til høyere arbeidstilbud. Tjenestepensjonene er i stor grad reformert og tilpasset alderspensjonsreformen.

\section{Andre sosialforsikringsreformer}

I flere av de nordiske landene pågår det også reformer i andre deler av sosialforsikringssystemet. Målet er å motvirke og redusere utenforskap av helsemessige grunner eller langtidsarbeidsledighet.

I Danmark har regjeringen nylig (2012) lagt fram forslag til en omfattende innsatspakke for "Et godt og langt arbejdsliv for alle." Forebygging av fysisk og psykisk slitasje og bedre forankring på arbeidsmarkedet er de to hovedelementene i innsatspakken.

I Finland står helse- og rehabiliteringsinnsats og -reformer sentralt for å forebygge og begrense avgang fra arbeidsmarkedet. En offentlig komité har (2009) lagt fram forslag til endringer i sosialforsikringssystemet. Målet er bedre insentiver til arbeid, motvirke fattigdom og bedre generasjonsfordeling.

Island prioriterer opprustning av boliger og hjemmebaserte helse- og omsorgstjenester for å heve livskvaliteten blant eldre.

Norge har reformert og forenklet den midlertidige inntektssikringen under medisinsk og arbeidsrettet rehabilitering og begrenset adgangen til førtidspensjonering via arbeidsledighetstrygden.

I Sverige er det gjennomført flere omfattende endringer i sosialforsikringssystemet, først og fremst i sykeforsikringen. Blant annet er inntektssikringen noe redusert, samtidig som det er innført strengere kontroll og oppfølging av langtidssykmeldte, med normerte varigheter for sykefravær osv. 


\section{Motvirke aldersdiskriminering, informasjon og holdningspåvirkning}

Alle nordiske land har innsatser for å motvirke diskriminering, usikkerhet og fordommer knyttet til eldre arbeidskraft, både gjennom lovgivning, informasjon og påvirkning.

Danmark har blant annet gjennomført en kampanje for å påvirke holdninger blant seniorer selv, kolleger og arbeidsgivere. ("Noen få ekstra år gjør en stor forskjell").

Finland har lagt vekt på å motvirke aldersdiskriminering på jobben gjennom flere initiativ og innsatser. Eldre ansattes opplevelse av aldersdiskriminering på jobben har avtatt med $30 \%$ på 2000-tallet.

Island har tradisjoner for å inkludere og verdsette seniorer og eldre, både i familie, arbeidsliv og organisasjonsliv.

I Norge skjer mye informasjon og holdningsskapende arbeid som ledd i trepartssamarbeidet om et inkluderende arbeidsliv. Senter for seniorpolitikk er en viktig aktør i dette arbeidet. Sverige har lovbestemt forbud mot aldersdiskriminering i arbeidslivet og en viss beskyttelse mot oppsigelse i "Lag om anställningsskydd" (LAS). Aldersdiskriminering skjer generelt som oftest i forbindelse med rekruttering og ansettelser.

\subsection{Hva kan vi lære av naboen?}

Deltakelsen i arbeidslivet blant seniorer i Norden er høyest i Island, etterfulgt av Sverige og Norge, og med lavest seniordeltakelse i Danmark og Sverige. Hva kan ligge bak?

Her søker vi å trekke fram de gode eksemplene som kanskje kan være til inspirasjon og lærdom for andre - i og utenfor Norden. Det er basert på våre studier som ledd i arbeidet med denne rapporten. Vi er opptatt av hva som kan se ut til å ha god virkning på seniorers deltakelse i arbeidslivet. Det er ikke basert på systematisk evaluering av oppnådde resultater og effekter, og derfor er det ikke sikkert vi yter alle land og ordninger rettferdighet. 


\section{De brede strategiene - økonomisk politikk, arbeidspolitikk og velferdspolitikk}

Det kan se ut til at Island og Norge har den mest eksplisitte produksjonsog arbeidsorienterte økonomiske politikken. Det er veldig tydelig at høy yrkesdeltakelse og velferd og inkludering for alle er hovedmål for den $\emptyset$ konomiske politikken. I de andre nordiske landene kan den økonomiske politikken synes mer orientert mot balanse i de offentlige budsjetter, blant annet som følge av krav og retningslinjer i EU. Island har få førtidspensjonsordninger og relativt lave pensjoner. Island har også tradisjon for å verdsette og inkludere seniorer og eldre. Sverige har tradisjonelt hatt stor beskyttelse av seniorer og folk med varige arbeidsforhold. Sverige var også først ute med en omfattende pensjonsreform for blant annet å stimulere til høyere yrkesdeltakelse. I Danmark har skiftende regjeringer lagt fram og gjennomført diverse større reformpakker for å fremme deltakelse og velferd for alle. I Finland har det tradisjonelt vært mange førtidspensjonsordninger og tradisjon for å gå av tidlig, også som ledd i arbeidsmarkedspolitikken. Dette har man i lang tid arbeidet med å snu, og dette har gitt resultater i stigende deltakelse i arbeidslivet blant seniorer.

\section{Arbeidsmarkeds- og arbeidsmiljøstrategier}

I Norge har trepartssamarbeidet mellom regjeringen og partene i arbeidslivet om et inkluderende arbeidsliv (IA) hatt en god innvirkning på seniorers deltakelse i arbeidslivet. Delmål 3 i IA-avtalen har eksplisitt gått ut på å få flere seniorer til å fortsette flere år i arbeid. Mye oppmerksomhet og mange tiltak og innsatser er satt inn, sentralt, bransjevis og ikke minst i de enkelte virksomheter. Dessuten har antakelig arbeidet med ny pensjonsreform gitt en del oppmerksomhetseffekter. I Sverige kan det se ut til at seniorer og personer med varige arbeidsforhold har relativt god beskyttelse, blant annet gjennom "Lag om anställningsskydd" og ved tradisjoner om ansiennitetsprinsipper ("sist inn, først ut"). Spørsmålet er om dette kan ha gått på bekostning av ungdom, funksjonshemmede og innvandrere? I Danmark er det som nevnt lansert diverse større "pakker" for å styrke deltakelsen i arbeidslivet. Deltakelsen blant seniorer er ikke gått ned under krisen, og den har økt litt blant 60-64-åringer. Vil de siste store satsingene på innsatspakker overfor unge, seniorer og personer med nedsatt arbeidsevne bidra til å øke deltakelsen i arbeidslivet? I Finland har det i mange år vært satset mye på forbyggende og helsefremmende arbeids- 
miljø. Er dette en viktig forklaring bak framgangen i Finland? Kan de andre nordiske landene ha noe å lære av dette?

\section{Pensjons- og andre sosialforsikringsreformer}

Sverige er som nevnt det landet som var først ute med en omfattende og banebrytende reform i pensjonssystemet, med sikte på bedre generasjonsbalanse, deltakelse i arbeidslivet og økonomisk trygghet i alderdommen. Mange andre pensjonsreformer har hatt den svenske reformen som modell, blant annet i Norge og Finland. Sverige har også nylig gjort omfattende endringer i sykeforsikringen for å redusere langtidssykefravær og utstøting fra arbeidslivet, og dette gir resultater. I Danmark har fleksjobbordningen og reformene i denne vært en foregangsmodell for forankring i arbeidslivet. Arbeid skal alltid være et realistisk førstevalg framfor tidlig pensjonering, med muligheter for å kombinere deltidsarbeid og delpensjon og mulighet til å gå inn og ut av arbeid og pensjon. Danmark er også det landet som har satt seg de tydeligste målene om å øke den generelle pensjonsalderen. Pensjonsreformen i Norge fra 2011 har antakelig gått lengst i muligheten til å velge og til å kombinere pensjon og arbeid fra fylte 62 år. Foreløpige tall for 2011 viser at mange tar ut pensjon, men at mange samtidig fortsetter i arbeid, forbausende ofte på deltid. I Finland er det spennende å se hva som kan komme ut av oppfølgingen av "SATA-komiteens" forslag til reformer i sosialforsikringssystemet for å fremme deltakelse i arbeidslivet og -inkludering.

\section{Informasjon, holdningspåvirkning, anti-diskriminering}

Sverige har tydelige og klare regler mot aldersdiskriminering og regler om oppsigelsesvern og annen beskyttelse av eldre arbeidskraft. Finland og Danmark satser friskt på informasjon og påvirkning på jobben - i den enkelte virksomhet og arbeidsplass. Danmarks kampanje "noen ekstra år gjør en stor forskjell" er et godt eksempel. I Norge er "Senter for seniorpolitikk" og det opplysnings- og påvirkningsarbeidet som de gjør sammen med partene i arbeidslivet og myndighetene, et eksempel på god praksis. 


\subsection{Definisjoner og forklaringer}

\section{Sysselsettingsrate (\%)}

Antall personer i arbeid i alderen 55-64 år i prosent av samlet folketall i aldersgruppen.

\section{Allmenn aldersgrense}

Fra den alderen man kan bli sagt opp på grunn av alder alene.

\section{Allmenn pensjonsalder}

Fra den alderen da alle innbyggere har rett til å ta ut allmenn alderspensjon.

\section{Fleksibel pensjonsalder}

Det aldersspenn der en selv kan velge å ta ut allmenn alderspensjon, gitt at en har tjent opp tilstrekkelige pensjonsrettigheter.

\section{Avgangsalder}

Gjennomsnittlig alder når personer mellom 50-70 år trekker seg ut av arbeidslivet, gitt at vedkommende var yrkesaktiv som 50 -åring.

\section{Antall år i arbeid}

Gjennomsnittlig antall år som personer 15-16 år og eldre er i arbeid i løpet av livet. 


\subsection{Figur- og tabellvedlegg - Seniorer}

Stigende eldrerater i de nordiske landene. Antall personer 65 år og eldre som prosent av antall personer 20-64 år i 2010, 2030 og 2050

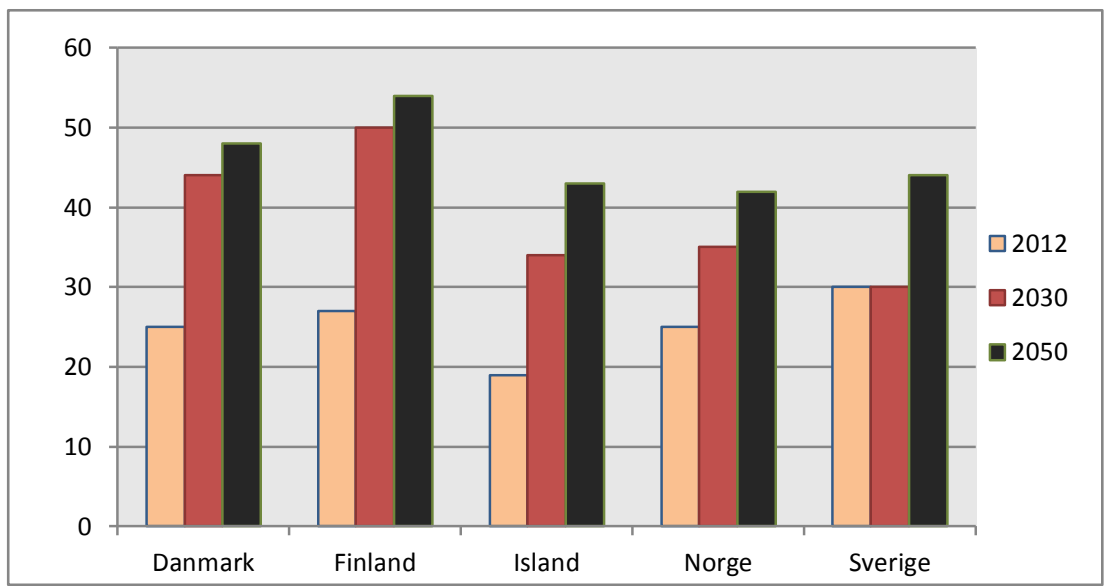

Kilde: Nordisk Socialstatistisk Komité (Nososko), Eurostat og egen bearbeiding NVC.

\section{Sysselsetting i Norden og EU-27 for personer 55-64 år (2001-2011)}

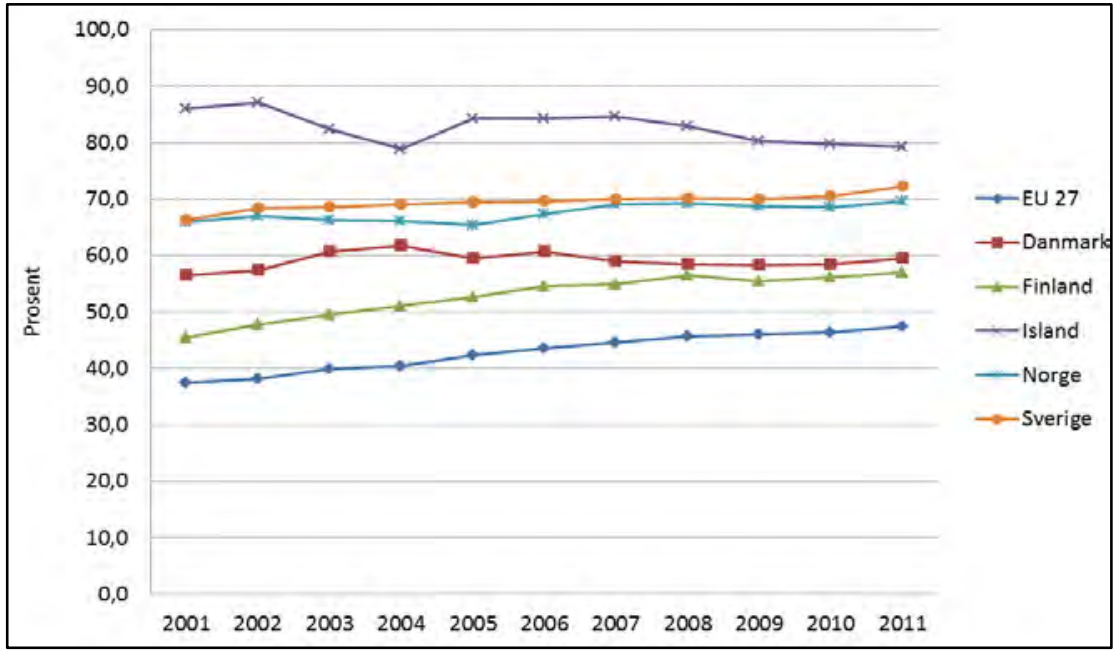

Källa: Eurostat LFS: Filnamn: Employment rates by sex, age and nationality (\%) [Ifsa_ergan]. Hentet fra http://epp.eurostat.ec.europa.eu/portal/page/portal/eurostat/home/ 21 nov 2012. Egen bearbeiding. 
Seniorer, arbeid og pensjonering i Norden 2011

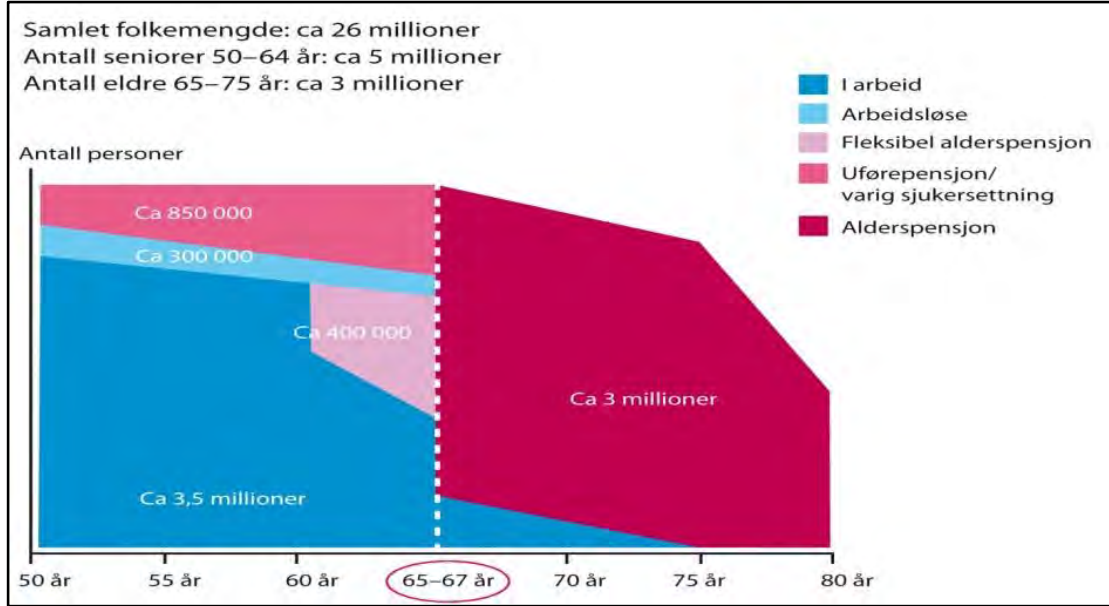

Kilder: Nasjonal, offentlig statistikk og egen bearbeiding NVC.

\section{Pensjoneringen tar fart fra 60 - årsalderen. Antall pensjonister i alt i prosent} av befolkningen 50 år og eldre i de nordiske landene år 2010

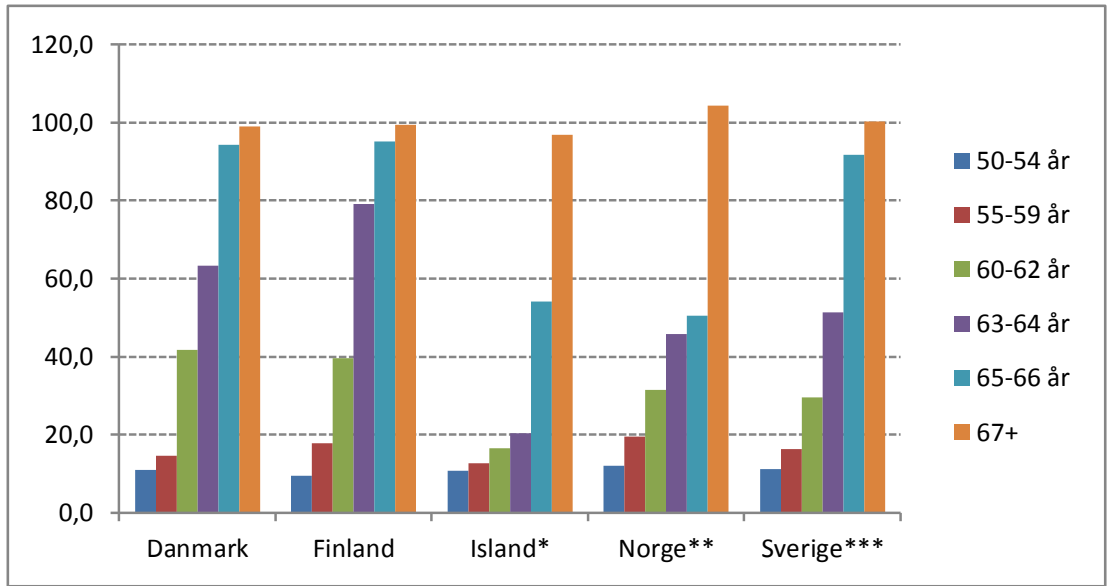

Kilde: Nordisk Socialstatistisk komité (Nososko) og egen bearbeiding NVC. 
Indikatorpanel - Seniorer i Norden. Deltakelse i arbeidslivet, avgang og pensjonering 2010/2011

\begin{tabular}{|c|c|c|c|c|c|}
\hline & Danmark & Finland & Island & Norge & Sverige \\
\hline \multicolumn{6}{|l|}{ Allmenn } \\
\hline Aldersgrense & 70 år & 68 år & 70 år & 70 år & 67 år \\
\hline \multicolumn{6}{|l|}{ Allmenn } \\
\hline \multicolumn{6}{|l|}{ Fleksibel } \\
\hline Pensjonsalder & 60 år og eldre ${ }^{3}$ & 63 år og eldre ${ }^{4}$ & 67 år og eldre & $62-75$ år & 61 år og eldre \\
\hline Avgangsalder & 62,3 & 62,4 & 64,5 & 63,5 & 64,4 \\
\hline \multicolumn{6}{|c|}{ Sysselsettingsrate \% } \\
\hline Menn & 63,8 & 56,8 & 82,0 & 72,9 & 75,7 \\
\hline Kvinner & 55,7 & 57,2 & 76,3 & 66,1 & 68,9 \\
\hline$M+K$ & 59,5 & 57,0 & 79,3 & 69,6 & 72,3 \\
\hline \multicolumn{6}{|c|}{ Antall år i arbeid } \\
\hline Menn & 41,1 & 37,4 & 46,4 & 40,6 & 41,6 \\
\hline Kvinner & 37,8 & 36,2 & 42,7 & 38,1 & 38,5 \\
\hline$M+K$ & 39,5 & 36,8 & 44,6 & 39,5 & 40,1 \\
\hline
\end{tabular}

Kilder: Eurostat (statistikk), nasjonale kilder/departementer (regler) og egen kartlegging (NVC).

${ }^{1}$ Folkepensjonsalderen stiger gradvis til 67 år for personer som er født etter 1953.

${ }^{2}$ Det finnes ingen formell pensjonsalder i det allmenne pensjonssystemet.

${ }^{3}$ Pensjonsutbetalingsalderen følger som utgangspunkt folkepensjonsalderen, og stiger dermed gradvis til 64 år.

${ }^{4}$ Fra 2013.

\section{Kilder og referanser}

For kilder og referanser, se hovedrapporten Det dreier seg om helse og arbeidsglede. Om seniorer, arbeid og pensjonering i Norden. 


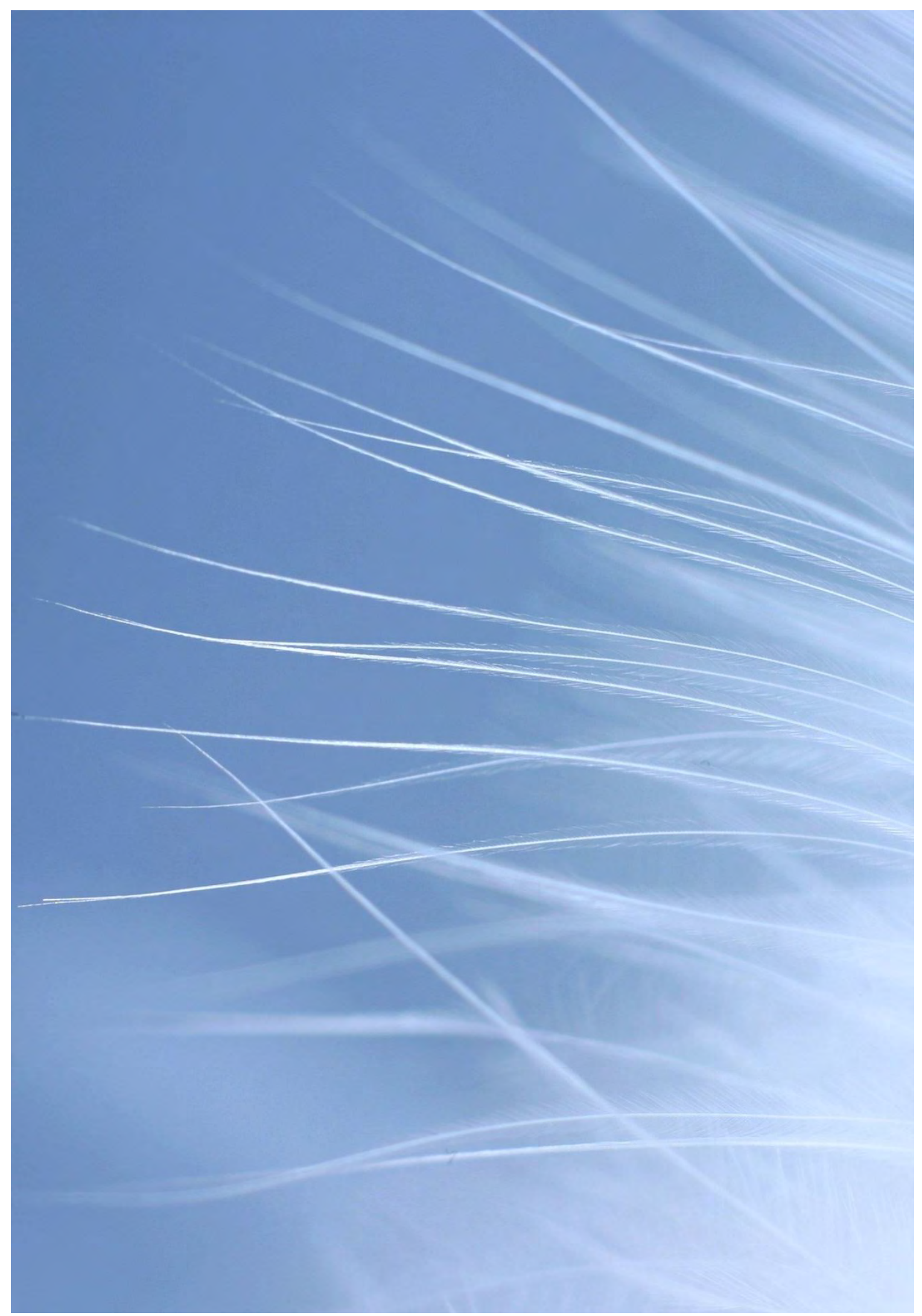




\section{Summary}

In the report $\AA$ skape et inkluderende arbeidsmarked. Om inkludering av unge, funksjonsnedsatte og seniorer i Norden (et sammendrag) (Eng. Creating an inclusive labour market. Inclusion of youths, people with disabilities and seniors in the Nordic countries (a summary)) three reports on labour market inclusion are summarized. The reports highlight in different ways the situation for vulnerable groups on the labour market in the Nordic countries; focus is on young people, people with disabilities and seniors (50+). The financial crisis in 2008, changed demographics and globalization are discussed in relation to the situation on the labour market and new policy initiatives.

Each report provides an update of the current situation on the labour market for one of the three groups. They also highlight successful initiatives and best practices in an inclusive labour market policy at an overall national level, but also local initiatives.

The first interim report presented is Unge på kanten (Young people on the edge). This report discusses the situation of young people in the labour market and in education in the Nordic countries.

Job applicants today meet an ever more specialized labour market and for young people, this may complicate labour market entry when the supply of unskilled jobs decreases. A sign that it has become harder for young people to enter the labour market is the ever rising age for labour market entry (the age when $75 \%$ of a cohort is employed). Since the global financial crisis of 2008, the labour market situation has deteriorated in the Nordic region as in the rest of the world. However, the five Nordic countries have done comparatively well in spite of the crisis and in Norway and Iceland; youth unemployment is still at a low level.

Young people looking for work often lack previous work experience and contacts; this contributes to making formal qualifications, such as educational background and achievements, even more important. For the young without satisfactory qualifications from upper secondary school, it 
becomes even harder to get a job. The report Unge på kanten (Young people on the edge) discusses the countries' initiatives to increase the proportion of young people who graduates from upper secondary education.

The second interim report has the title Et arbeidsmarked for alle? En dokumentanalyse av de nordiske landenes jobbstrategier for personer med funksjonsnedsettelse. (A labour market for all? A documentary analysis of job strategies in the Nordic countries for people with disabilities.) This report provides a brief introduction to the situation for people with disabilities in the labour market in the Nordic countries, and then discussing the latest policy strategies in the area in each of the countries.

For people with disabilities, it is difficult to get work, even in countries where unemployment is otherwise low. ${ }^{16}$ There seems to be a high degree of stigmatization and ignorance that makes labour market entry difficult for people in this group. The governments of the Nordic countries propose several new initiatives in order to change and improve the labour market situation of people with disabilities. These initiatives are discussed and analysed in the report.

One of the conclusions from Et arbeidsmarked for alle? (A labour market for all?) is that many initiatives focus on the supply side of the labour market, i.e. job seekers and employees, and a lot fewer initiatives focus on the demand side, i.e. employers. The report also reveals that there is quite a lot of ignorance among employers on available support and additional resources to hire people with disabilities.

The third report Det dreier seg om helse og arbeidsglede. Om seniorer, arbeid og pensjonering i Norden (A matter of health and job satisfaction. Seniors, work and retirement in the Nordic region) is about the situation of seniors (50+) on the labour market in the Nordic region. Senior workers have a stronger position than younger people in the labour market; they often have relevant work experience and a wider network of contacts.

\footnotetext{
${ }^{16}$ In Sweden, a distinction is made in the statistics between people with disabilities who also have reduced capacity to work and people with disabilities without reduced work capacity. In the group of people with disabilities without reduced work capacity, employment has been higher than for the population in general at several measurement occasions.
} 
Many countries also protect older workers' employment through so-called "first-in, last-out" rules.

Despite the fact that seniors in many ways are well positioned in the labour market, there is an alarming proportion that drops out of the workforce prematurely. The main path of exit from the labour market occurs due to disease and ill-health. As a result of the demographic changes that mean a smaller proportion of people in the labour market, while the dependency ratio increases, it becomes increasingly important that all people of working age get a job and can work.

The report discusses the myths and conceptions of seniors participating in the labour market and good examples of how they can work more often and longer, for the benefit of both employers and employees. One of the conclusions of the report is about the importance of promoting a healthy work environment in order for more people to have the energy and desire to work longer.

The report compares and analyses strategies for the labour market and working environment, pension system reforms, age limits and social security. One of the report's recommendations is about fighting age discrimination through increased information and changing of attitudes.

The three reports and this synthesis report are also available in a condensed version in English with the exception of Et arbeidsmarked for alle? (A labour market for all?). All reports can be ordered or downloaded from the Nordic Centre for Welfare and Social Issues' website www.nordicwelfare.org or from the Nordic Council of Ministers' website www.norden.org. 
Nordisk ministerråd

Ved Stranden 18

DK-1061 København K

www.norden.org

\section{Å skape et inkluderende arbeidsmarked}

Høy deltakelse i arbeidslivet er fundamentet for den nordiske velferden. Arbeidskraften er vår viktigste ressurs og i alle de nordiske landene er målet at flest mulig skal kunne delta i arbeidslivet. Arbeid gir identitet og bidrar til økonomisk selvstendighet, deltagelse og sosial tilhørighet. Det gir den enkelte anledning til å utvikle og bruke sine evner.

I all velstanden er det likevel faresignaler. Et stort antall unge faller ut av skole og utdanning, og mange får dermed problemer med å komme inn på arbeidsmarkedet. Mennesker med nedsatt funksjonsevne har problemer med å få arbeid og mange seniorer går tidlig ut av arbeidslivet. I rapporten $\AA$ skape et inkluderende arbeidsmarked: Om inkludering av unge, funksjonsnedsatte og seniorer i Norden (et sammendrag) diskuteres hva som gjøres og hva som er oppnådd i de nordiske landene med å inkludere disse gruppene på arbeidsmarkedet.
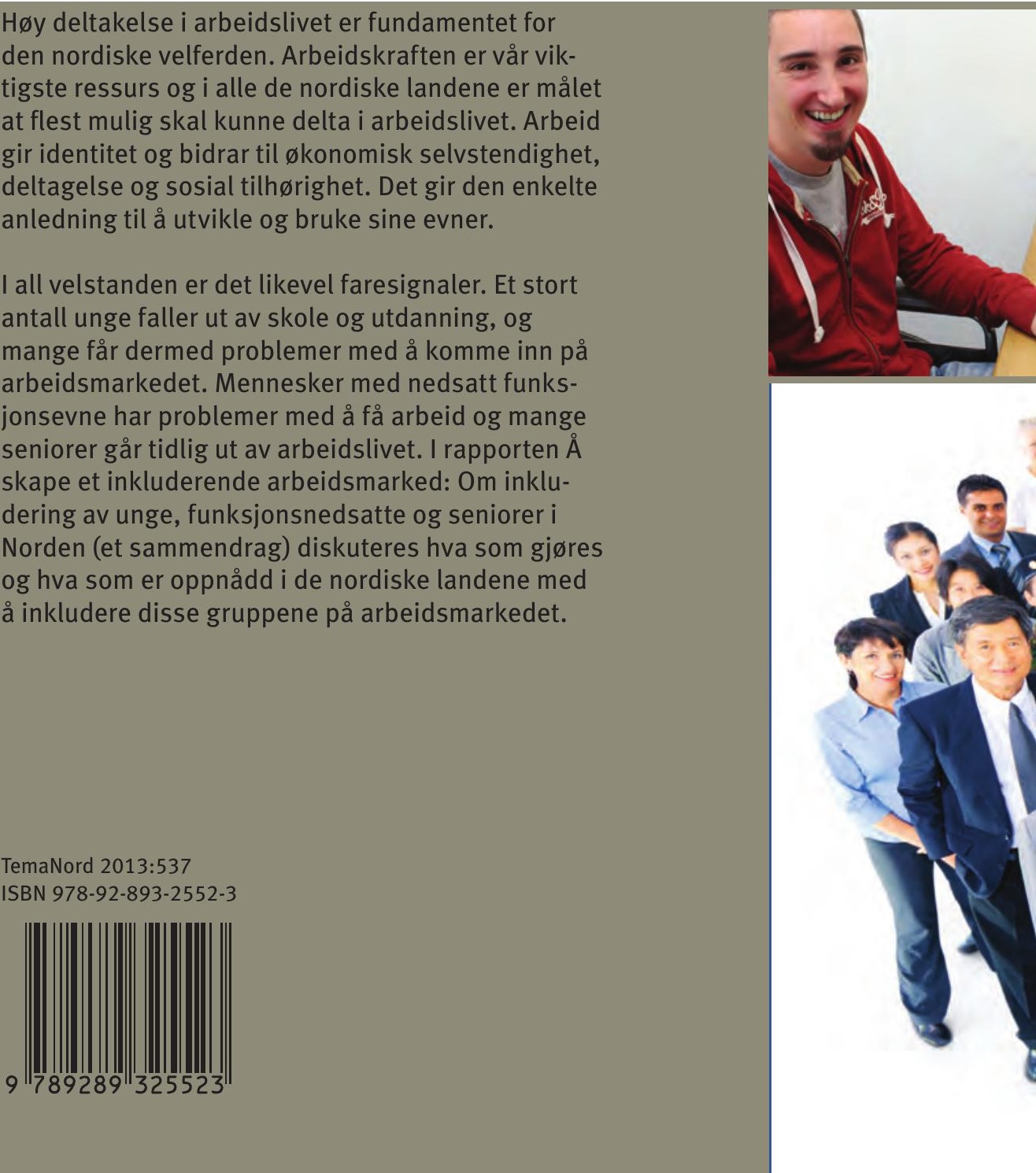